\title{
O CONTROLE DE CONVENCIONALIDADE E SUA APLICABILIDADE AO DIREITO PENAL BRASILEIRO
}

\section{CONVENTIONALITY CONTROL AND ITS APPLICABILITY TO BRAZILIAN CRIMINAL LAW}

\author{
Gabriel Benedito Issaac Chalita ${ }^{1}$ \\ Silmar Fernandes ${ }^{2}$
}

\begin{abstract}
RESUMO
O presente artigo pretende discorrer sobre o controle de convencionalidade e sua aplicabilidade ao Direito Penal brasileiro, a partir de uma análise do que se entende efetivamente por controle de convencionalidade, ou seja, do seu conceito, legitimidade e modo de implementação ou realização. Objetiva-se, com isso, verificar as condições de sua efetividade, à luz do que dispõe a legislação, a doutrina especializada e a jurisprudência. A metodologia adotada é a pesquisa bibliográfica e documental, de caráter qualitativo. Espera-se como resultado contribuir com o avanço dos estudos de Teoria do Direito focalizando em específico os aspectos propedêuticos do Direito Penal e do Direito Internacional Público.
\end{abstract}

Palavras-chave: controle de convencionalidade; direito penal; princípio da legalidade.

\begin{abstract}
This article intends to discuss the control of conventionality and its applicability to Brazilian Criminal Law, from an analysis of what is effectively understood by control of conventionality, that is, of its concept, legitimacy and mode of implementation or realization. The objective is, therefore, to verify the conditions of its effectiveness, in the light of the legislation, specialized doctrine and jurisprudence. The adopted methodology is the bibliographic and documentary research, of qualitative character. As a result, it is expected to contribute to the advancement of Law Theory studies focusing specifically on the propaedeutic aspects of Criminal Law and Public International Law.
\end{abstract}

\footnotetext{
${ }^{1}$ Possui graduação em Direito pela Pontifícia Universidade Católica de São Paulo (1994), graduação em Filosofia pela Faculdade Salesiana de Filosofia Ciências e Letras de Lorena (1989), mestrado em Ciências Sociais pela Pontifícia Universidade Católica de São Paulo (1995), mestrado em Direito pela Pontifícia Universidade Católica de São Paulo (1997), doutorado em Comunicação e Semiótica pela Pontifícia Universidade Católica de São Paulo (1997) e doutorado em Direito pela Pontifícia Universidade Católica de São Paulo (1998). Atualmente é professor da Universidade Presbiteriana Mackenzie; professor da Pontifícia Universidade Católica de São Paulo, professor da Universidade Nove de Julho - Uninove e professor do IBMEC-SP. Pontifícia Universidade Católica de São Paulo; Universidade Nove de Julho; Universidade Presbiteriana Mackenzie e IBMEC - Brasil. ORCID: https://orcid.org/0000-0002-4432-9954 Lattes: http://lattes.cnpq.br/1580592043070785 E-mail: wilsonlevy@hotmail.com

${ }^{2}$ Aluno do Mestrado do Programa de Pós-Graduação Stricto-Sensu em Direito da Universidade Nove de Julho. Desembargador no TJSP e no TRESP. Professor de Direito Penal na Faculdade de Direito da Universidade Presbiteriana Mackenzie e nos Cursos de Pós-Graduação da Escola Paulista da Magistratura. Universidade Nove de Julho - $\quad$ Brasil. ORCID: https://orcid.org/0000-0002-2228-2323 Lattes: http://lattes.cnpq.br/2472719225181629 E-mail: sfernandes@tjsp.jus.br
} 
Keywords: conventionality control, criminal law, principle of legality.

\section{INTRODUÇÃO}

Trata o presente artigo sobre o controle de convencionalidade e sua aplicabilidade ao Direito Penal brasileiro, a partir de uma análise do que se entende efetivamente por controle de convencionalidade, ou seja, do seu conceito, legitimidade e modo de implementação ou realização.

Com efeito, havia uma discussão acerca da natureza jurídica dos tratados e convenções internacionais de direitos humanos internalizados ao ordenamento jurídico pátrio antes da promulgação da Emenda Constitucional 45/2004. Isto porque tal emenda acrescentou o $\S^{\circ}$ ao artigo $5^{\circ}$ da Constituição Federal, dispondo que "os tratados e convenções internacionais sobre direitos humanos que forem aprovados, em cada Casa do Congresso Nacional, em dois turnos, por três quintos dos votos dos respectivos membros, serão equivalentes às emendas constitucionais". Ocorre que já havia tratados de direitos humanos internalizados ao ordenamento sem seguir esse procedimento e, se por uma lado, pareceu evidente que eles não possuíam status de norma constitucional,por outro, parecia equivocado atribuir-lhes apenas status de lei ordinária quando a própria Constituição outorgou à matéria por eles veiculada (direitos humanos) papel de destaque.

Diante disto, o Supremo Tribunal Federal, em 2008, ao discutir a prisão civil do depositário infiel que, embora admitida pela legislação ordinária, era vedada pela Convenção Americana de Direitos Humanos (Pacto de São José da Costa Rica), internalizada pelo Brasil antes da Emenda Constitucional 45/2004, reconheceu a natureza supralegal dos tratados e convenções internacionais sobre direitos humanos que fossem ratificados sem seguir o quórum qualificado de emenda, conforme tese capitaneada pelo Ministro Gilmar Mendes. Ao assim fazê-lo, entretanto, a Corte Suprema acrescentou mais um degrau à pirâmide normativa, relativo à norma supralegal que estaria abaixo da Constituição, mas acima das demais leis infraconstitucionais.

E como o sistema deve guardar coerência, de modo que não haja conflitos reais entre as normas, a solução encontrada, então, foi estabelecer que tais leis infraconstitucionais devem guardar compatibilidade material também com os tratados e convenções internacionais de 
direitos humanos não internalizados nos termos do $\$ 3^{\circ}$ do artigo $5^{\circ}$ da Carta Magna (norma supralegal), o que é aferível via controle de convencionalidade, ora objeto de estudo.

De fato, buscou-se compreender em que efetivamente consiste o chamado controle de convencionalidade e, posteriormente, se é possível sua realização no âmbito penal, conhecido pelos seus rigores técnicos e principalmente por ser regido pelo princípio da estrita legalidade.

Assim, a primeira parte deste ensaio destina-se à conceituação e caracterização do controle de convencionalidade; a segunda à contextualização do Direito Penal e suas regras e, por fim, à possibilidade de aplicação do controle de convencionalidade em âmbito penal.

\section{O CONTROLE DE CONVENCIONALIDADE.}

Não obstante o estudo e sistematização do controle de convencionalidade sejam recentes na doutrina e jurisprudência brasileira, como se verá adiante, o tema em si não é novo. Seu aparecimento se deu, efetivamente, com a promulgação da Constituição Federal de 1988 que assim dispôs em seu artigo $5^{\circ}$, parágrafo $2^{\circ}$ :

(...) Os direitos e garantias expressos nesta Constituição não excluem outros decorrentes do regime e dos princípios por ela adotados, ou dos tratados internacionais em que a República Federativa do Brasil seja parte.

Como se pode observar, com o dispositivo mencionado, o ordenamento jurídico brasileiro adotou a cláusula da complementariedade, ou seja, o princípio segundo o qual o rol de direitos humanos ${ }^{3}$ reconhecidos pelo direito internacional serve de complemento ao catálogo de direitos fundamentais previstos pelo direito interno (BERNARDES; FERREIRA, 2015, t. I, p. 639). E, justamente em razão deste dispositivo, parte da doutrina passou a sustentar que os direitos humanos enunciados em tratados internacionais teriam o status de norma constitucional. A professora Flávia Piovesan (1997, p. 59) assim prelecionava:

“(...) ainda que estes direitos não sejam enunciados sob a forma de normas constitucionais, mas sob a forma de tratados internacionais, a Constituição lhes confere o valor jurídico de norma constitucional, já que preenchem e

\footnotetext{
${ }^{3}$ Sobre a utilização das expressões "direitos humanos" e "direitos fundamentais": "A expressão direitos humanos costuma referir-se a direitos correspondentes ao gênero humano, sem importar com a peculiaridades e características das diversas comunidades existentes em cada núcleo estatal (religiões, etnias, sistemas socioeconômicos). Assim, a questão dos direitos humanos é tratada de maneira supranacional, no âmbito do direito público internacional, sobretudo por organismos multilaterais como a ONU (...). Já os direitos fundamentais são objeto do direito público interno de cada Estado, especificamente do direito constitucional. Trata-se de direitos do homem "objectivamente vigentes numa ordem jurídica concreta" (CANOTILHO 1993, p. 517)” (BERNARDES; FERREIRA, 2015, t. I,p. 623).
} 
complementam o catálogo de direitos fundamentais previstos pelo texto constitucional".

A partir daí, ao menos em tese, era possível se cogitar da necessidade de se aferir a compatibilidade material das leis comuns com os tratados que versassem sobre direitos humanos, em uma espécie de controle que posteriormente se denominou de controle de convencionalidade.

Entretanto, mesmo após a promulgação da Carta Magna, o Supremo Tribunal Federal continuou a aplicar a tese prevalecente desde o julgamento do Recurso Extraordinário 80.004, julgado em 01.06.1977, segundo a qual os tratados em geral - versassem ou não sobre direitos humanos - se incorporariam ao direito interno no mesmo plano de validade e hierarquia das leis ordinárias (STF, ADIn 1.480/DF e AgRg na Carta Rogatória 8.279). Assim, as normas decorrentes dos tratados poderiam afastar a aplicação das normas de direito interno porque posteriores (critério cronológico) e específicas (critério da especialidade), e não porque superiores à legislação ordinária (critério hierárquico). Justamente, por isso, não se falava em aferição de compatibilidade material entre as normas internas e os tratados internacionais.

Posteriormente, com a Emenda Constitucional n ${ }^{\circ} 45$ de 2004, foi incluído o $§ 3^{\circ}$ ao artigo $5^{\circ}$ da Carta Magna, com o seguinte teor:

(...) Os tratados e convenções internacionais sobre direitos humanos que forem aprovados, em cada Casa do Congresso Nacional, em dois turnos, por três quintos dos votos dos respectivos membros, serão equivalentes às emendas constitucionais.

Com a inovação mencionada, ficou evidente a importância dos tratados e convenções sobre direitos humanos, os quais, quando aprovados de acordo com o processo legislativo especial previsto no dispositivo em comento terão o status de norma constitucional e, portanto, poderão servir de parâmetro ao controle de constitucionalidade.

A partir daí a questão centrou-se naqueles tratados e convenções internacionais sobre direitos humanos que haviam sido internalizados antes da Emenda Constitucional 45/2004 e que, portanto, não seguiram o procedimento legislativo descrito no artigo $5^{\circ}, \S 3^{\circ}$ da Carta Magna. Se por um lado parecia óbvio que eles não possuíam status de norma constitucional, ante a ausência da formalidade relativa ao procedimento, por outro parecia equivocado atribuirlhes apenas status de lei ordinária quando a própria Constituição outorgou a matéria por eles veiculada (direitos humanos) papel de destaque.

$\mathrm{Na}$ doutrina brasileira, quem desenvolveu, pela primeira vez, de maneira sólida e com precisão técnica, a questão da hierarquia dos tratados e a teoria do controle de 
convencionalidade foi Valério Mazzuoli, em sua tese de doutoramento, sustentada na Faculdade de Direito da Universidade Federal do Rio Grande do Sul, em 04 de novembro de 2008, publicada 02 (dois) anos depois sob o título Tratados internacionais de direitos humanos $e$ direito interno, pela editora Saraiva. O que ali se defendeu foi rapidamente absorvido pela doutrina e jurisprudência brasileira, inclusive pelo Supremo Tribunal Federal que, aos 03 de dezembro de 2008, julgou em conjunto, na mesma sessão Plenária, o Recurso Extraordinário n ${ }^{\circ}$ 466.343/SP, o Recurso Extraordinário n ${ }^{\circ} 349.703 / \mathrm{RS}$ e os Habeas Corpus no 87.585/TO e n ${ }^{\circ}$ 92.566/SP, todos versando sobre a possibilidade de prisão do depositário infiel e discutindo a hierarquia normativa dos tratados internacionais.

Naquela oportunidade, a Corte Suprema atribuiu aos tratados internacionais de direitos humanos ratificados pelo Brasil, porém, sem seguir o procedimento de emenda constitucional, o status de norma supralegal e afirmou que lei ordinária em conflito com tais tratados teria sua eficácia jurídica paralisada. Estabeleceu-se, pois, a possibilidade de um controle chamado de convencionalidade, cujos conceito e características serão a seguir delineados.

\subsection{CONCEITO}

Segundo Valério Mazzuoli (2016, p. 31), o controle de convencionalidade refere-se à aferição da compatibilidade vertical material das normas de direito interno com as convenções internacionais de direitos humanos em vigor no país. É especialmente o estudo da técnica judicial, seja internacional ou interna, de compatibilização vertical das leis com tais preceitos internacionais.

A expressão "controle de convencionalidade" refere-se ao fato de que grande parte dos atos internacionais são firmados a partir de convenções, ou seja, atos multilaterais assinados em conferências internacionais e que versam sobre assuntos de interesse geral. São, em verdade, uma espécie de convênio entre dois ou mais países sobre os mais variados temas - questões comerciais, industriais, relativas a direitos humanos (GOVERNO DO BRASIL, 2012).

Entre nós a obrigação convencional provém da Convenção Americana de Direitos Humanos, mais conhecida por Pacto de São José da Costa Rica, incorporada ao Direito Brasileiro através do Decreto ${ }^{\circ}$ 678, de 06 de novembro de 1992.

Com efeito, dispõe a mencionada convenção, em seus artigos $1^{\circ}$ e $2^{\circ}$, que os Estados Partes devem respeitar os direitos e liberdades nela reconhecidos e garantir seu livre e pleno exercício a toda pessoa que esteja sujeita a sua jurisdição. Não bastasse, estabelece expressamente 
em seu artigo 43 que "os Estados Partes obrigam-se a proporcionar à Comissão as informações que esta lhes solicitar sobre a maneira pela qual o seu direito interno assegura a aplicação efetiva de quaisquer disposições desta Convenção" (CIDH, 1969).

Não obstante, a temática do controle de convencionalidade ganhou relevo no continente americano apenas no ano de 2006 quando a Corte Interamericana de Direitos Humanos, ao julgar o caso "Almonacid Arellano e outros Vs. Chile", assim consignou:

"124. A Corte tem consciência de que os juízes e tribunais internos estão sujeitos ao império da lei e, por isso, são obrigados a aplicar as disposições vigentes no ordenamento jurídico. Mas quando um Estado ratifica um tratado internacional como a Convenção Americana, seus juízes, como parte do aparato estatal, também estão submetidos a ela, o que os obriga a velar para que os efeitos das disposições da Convenção não se vejam diminuídos pela aplicação de leis contrárias a seu objeto e a seu fim e que, desde o início, carecem de efeitos jurídicos. Em outras palavras, o Poder Judiciário deve exercer uma espécie de "controle de convencionalidade" entre as normas jurídicas internas aplicadas a casos concretos e a Convenção Americana sobre Direitos Humanos. Nesta tarefa, o Poder Judiciário deve levar em conta não apenas o tratado, mas também a interpretação que a Corte Interamericana, intérprete última da Convenção Americana, fez do mesmo" (grifo não original) (CIDH, 2006).

Sobre o tema, explica a doutrina:

"Expressão originalmente criada em voto do jurista mexicano GARCíA
RAMÍREZ, na Corte Interamericana de Direitos Humanos, já se fala também, no
Brasil, em controle de convencionalidade. Trata-se de nomenclatura utilizada para
se referir ao exame da compatibilidade do direito nacional em face dos tratados e
convenções de direitos humanos. Pela teoria do controle de convencionalidade,
os juízes nacionais estão habilitados, no caso concreto, a fazer o controle (difuso)
da conformidade entre o direito doméstico e as normas decorrentes da
incorporação, ao ordenamento jurídico interno, dos tratados e convenções
internacionais sobre direitos humanos, especialmente a Convenção
Interamericana de Direitos Humanos - Pacto de San José"(BERNARDES;
FERREIRA, 2015, t. I, p. 341).

Portanto, falar de controle de convencionalidade é falar na aferição da compatibilidade material, o que pressupõe, portanto, a existência de hierarquia entre as normas do direito interno (inferiores) e os tratados e convenções internacionais sobre direitos humanos (superiores). Essa relação de hierarquia será detalhada adiante. Antes, porém, deve-se estabelecer a quem compete a realização de tal controle. 


\subsection{LEGITIMIDADE}

Preliminarmente, deve-se destacar que os tribunais regionais internacionais exercem o controle de convencionalidade e, quanto a isto, aliás, nunca houve dúvidas. Afinal, trata-se de uma de suas funções essenciais.

Não obstante, a partir de decisão dos próprios tribunais internacionais (vide o caso julgado pela Corte Interamericana de Direitos Humanos citado no item 1.1), passou-se a entender que os juízes internos também têm a função de aferir a compatibilidade entre as normas domésticas e as normas oriundas de tratados e convenções internacionais que tratem de direitos humanos e que tenham sido ratificados e estejam em vigor no país.

Haveria, portanto, nos dizeres de Valério Mazzuoli(2016, p. 31), dois modelos de controle de convencionalidade, um realizado de modo coadjuvante e complementar pelas cortes internacionais e outro levado a efeito especialmente, mas não exclusivamente, pelos juízes e tribunais nacionais em primeiro plano. Diz-se não exclusivo porque, assim como no controle de constitucionalidade em que há a possibilidade de controle preventivo, ou seja, aquele exercido anteriormente à promulgação da norma, pelos Poderes Legislativo e Executivo, também em relação ao controle de convencionalidade deve admitir-se tal hipótese. Afinal, não faria sentido algum permitir que uma norma flagrantemente inconvencional ingressasse no ordenamento jurídico interno. Como explica o professor Ingo Sarlet (2015b),

\footnotetext{
“(...) há que considerar que o controle de convencionalidade (interno) não é um controle exclusivamente jurisdicional e igualmente há de ser sublinhado e talvez possa merecer alguma atenção adicional como hipótese plausível. O Poder Legislativo, quando da apreciação de algum projeto de lei, assim como deveria sempre atentar para a compatibilidade da legislação com a CF, também deveria assumir como parâmetro os tratados internacionais, o que, de resto, não se aplica apenas aos tratados de direitos humanos, mas deveria ser levado ainda mais a sério nesses casos. Não se pode olvidar que a legislação interna incompatível com algum tratado ratificado pelo Brasil e que esteja em vigor na esfera supranacional configura violação do tratado, cabendo ao Poder Legislativo operar de modo preventivo também nessa seara.

Da mesma forma, o Chefe do Executivo poderia vetar lei aprovada pelo Legislativo quando detectar violação de tratado internacional, ainda que não se cuide aqui de um veto justificado pela eventual inconstitucionalidade da lei, a não ser no caso de tratado aprovado pelo rito do artigo $5^{\circ}$, parágrafo $3^{\circ}$, da $\mathrm{CF}$, onde, pelo menos assim o sugerimos, o tratado - mesmo de acordo com o entendimento do STF - integra, ao menos em geral, o bloco de constitucionalidade brasileiro, para além de integrar também um 'bloco de convencionalidade"”.
}

Por outro lado, diz-se essencialmente porque, assim como no controle de constitucionalidade em que o controle repressivo que visa a declarar a inconstitucionalidade de 
ato normativo em momento posterior à respectiva promulgação é, em regra, exercido pelo Poder Judiciário, também no controle de convencionalidade o exercício se dará prioritariamente pelos juízes e tribunais.

Não obstante, deve-se destacar que esse controle judicial não deve se dar de forma mecânica, com a simples análise de compatibilidade entre a norma interna e o tratado de direitos humanos ratificado e em vigor no país. Assim como o Juiz, ao julgar a inconstitucionalidade de uma lei, deve analisar, além de sua conformidade com a Constituição Federal, a existência de pronunciamento anterior do Supremo Tribunal Federal sobre o tema ${ }^{4}$, também no controle de convencionalidade deverá o Magistrado averiguar a existência de pronunciamento anterior da Corte Interamericana de Direitos Humanos sobre a questão objeto de análise (ou de pronunciamento de outra corte internacional responsável por aplicar e fiscalizar tratado ou convenção ratificado pelo Brasil), sempre aplicando, no caso concreto, a norma que for mais benéfica ou mais protetiva ao ser humano sujeito de direitos (princípio pro homineou pro persona).

Neste sentido, consignou a própria Corte (2006), ao julgar o caso “AlmonacidArellano e outros Vs. Chile", antes descrito, dispondo em seu artigo 124 que "o Poder Judiciário deve levar em conta não apenas o tratado, mas também a interpretação que a Corte Interamericana, intérprete última da Convenção Americana, fez do mesmo".

Por fim, deve-se destacar que todo juiz nacional pode proceder a análise da compatibilidade das normas domésticas com os tratados e convenções internacionais de direitos humanos ratificados e vigente no Brasil, de ofício e antes da análise do mérito, em preliminares, assim como faz no controle difuso de constitucionalidade. Em verdade, "a sua atuação é direta e não requer pedido do interessado, tampouco autorização constitucional ou legislativa para tanto, pois decorrente da jurisprudência vinculante da Corte” (MAZZUOLI, 2016, p.40).

\subsection{MODO DE IMPLEMENTAÇÃO.}

Conforme já mencionado, entre nós, Valério Mazzuoli foi o primeiro a tratar do controle de convencionalidade e, para ele, todos os tratados e convenções internacionais de direitos humanos - frise-se todos -, ratificados pelo Brasil e em vigor, têm o status de norma

\footnotetext{
${ }^{4}$ Neste sentido, dispõe o artigo 949, parágrafo único do Código de Processo Civil vigente, in verbis: "949. (...) Parágrafo único. Os órgãos fracionários dos tribunais não submeterão ao plenário ou ao órgão especial a arguição de inconstitucionalidade quando já houver pronunciamento destes ou do plenário do Supremo Tribunal Federal sobre a questão.
} 
constitucional. Não importa se aprovado com o quórum estabelecido no artigo $5^{\circ}, \S^{\circ}$ da Constituição Federal, equivalente ao quórum exigido para a aprovação de emenda, ou não. Todos os documentos internacionais sobre direitos humanos têm índole constitucional, seja uma hierarquia somente material (a norma teria status de norma constitucional por força do $\S 2^{\circ}$ do art. $5^{\circ}$ da $\mathrm{CF}$ ), seja uma hierarquia material e formal (nesse caso, a norma teria status equivalente à emenda constitucional por força do $\S 3^{\circ}$ do dispositivo mencionado).

Para o autor, portanto, o controle de convencionalidade poderia ser implementado tanto pela via difusa quanto pela via concentrada. $\mathrm{O}$ tratado ou convenção de direitos humanos ratificado pelo Brasil sem seguir o procedimento equivalente à incorporação de emenda constitucional apenas poderia ser objeto de controle na via difusa, o que seria possível em razão de tal normativa internacional ingressar no ordenamento pátrio com status de norma constitucional, por força do artigo $5^{\circ}, \S 2^{\circ}$ da Constituição Federal. Já o tratado ou convenção sobre a temática dos direitos humanos incorporado ao direito brasileiro nos moldes do $\$ 3^{\circ}$ do dispositivo em comento, por seguir o procedimento previsto para a aprovação de uma emenda constitucional, a ela equivaleria e, portanto, poderia ser parâmetro de controle de convencionalidade tanto de maneira difusa quanto concentrada, ou seja, poderia ser realizado por todo e qualquer juiz ou tribunal (controle difuso) ou pelo Supremo Tribunal Federal, a partir da propositura de ações do controle abstrato pelos legitimados constitucionais. Neste sentido,

\begin{abstract}
“(...) a produção normativa doméstica conta com um duplo limite vertical material: $a)$ a Constituição e os tratados de direitos humanos $\left(1^{\circ}\right.$ limite $)$ e $b$ ) os tratados internacionais comuns ( $2^{\circ}$ limite) em vigor no país. No caso do $1^{\circ}$ limite, relativo aos tratados de direitos humanos, estes podem ter sido ou não aprovados com o quórum qualificado que o art. $5^{\circ}, \S 3^{\circ}$ da Constituição prevê. Caso não tenham sido aprovados com essa maioria qualificada, seu status será de norma (somente) materialmente constitucional, o que lhes garantem serem paradigma (apenas) do controle difuso de convencionalidade; caso tenham sido aprovados (e entrado em vigor no plano interno, após sua ratificação) pela sistemática do art. $5^{\circ}, \S 3^{\circ}$, tais tratados serão material e formalmente constitucionais, e assim servirão também de paradigma do controle concentrado (para além, é claro, do difuso) de convencionalidade das leis.

Os tratados de direitos humanos paradigma do controle concentrado autorizam que os legitimados para a propositura das ações do controle abstrato (ADIn, ADECON, ADPF etc.), previsto no art. 103 da Constituição de 1988, proponham tais medidas no STF como meio de retirar a validade de norma interna (ainda que compatível com a Constituição) que viole um tratado internacional de direitos humanos em vigor no país" (MAZZUOLI, 2016, p. 20).
\end{abstract}

No que tange aos tratados e convenções internacionais comuns, ou seja, aqueles que não tratam de direitos humanos, Mazzuoli entende que eles servem de paradigma ao controle de supralegalidade, ou seja, dever-se-ia aferir a compatibilidade das normas infraconstitucionais com tais documentos internacionais. Em suas palavras, 
"o sistema brasileiro de controle da produção normativa doméstica também conta (especialmente depois da EC 45/2004) com um controle jurisdicional da convencionalidade das leis (para além do clássico controle constitucionalidade) e ainda com um controle de supralegalidade das normas infraconstitucionais" (MAZZUOLI, 2016, p. 19).

Assim, para Valério Mazzuoli, existe (i) o controle de legalidade, ou seja, a análise de compatibilidade vertical entre normas secundárias, como os decretos regulamentares, e as leis de onde advém sua validade ${ }^{5}$; (ii) o controle de supralegalidade, relativo à compatibilidade vertical entre as normas infraconstitucionais e os tratados internacionais comuns, os quais são superiores e, portanto, servem de paradigma ao referido controle; (iii) o controle de convencionalidade difuso, existente quando o paradigma é tratado ou convenção internacional sobre direitos humanos, internalizado ao ordenamento jurídico brasileiro seguindo ou não o rito estabelecido no artigo $5^{\circ}, \S 3^{\circ}$ da Constituição Federal; (iv) o controle de convencionalidade concentrado, apenas possível de ocorrer quando se questiona a compatibilidade material entre normas infraconstitucionais e tratado ou convenção sobre direitos humanos internalizada nos moldes do dispositivo antes mencionado ${ }^{6}$; e, finalmente, (v) o controle de constitucionalidade, sempre aferível pela via difusa ou concentrada.

Não obstante, não foi este o esquema normativo adotado pelo Supremo Tribunal Federal e tampouco o modo como se implementaria o controle de convencionalidade.

A Corte Suprema, aos 03 de dezembro de 2008, proferiu uma das decisões mais importantes de sua história. Ao julgar em conjunto, na mesma sessão plenária, o Recurso Extraordinário no 466.343/SP, o Recurso Extraordinário n³ 349.703/RS e os Habeas Corpus $\mathrm{n}^{\circ}$ 87.585/TO e $\mathrm{n}^{\circ}$ 92.566/SP, todos versando sobre a possibilidade de prisão do depositário infiel, o Supremo Tribunal Federal finalmente reconheceu que os tratados de direitos humanos incorporados ao ordenamento interno sem seguir o procedimento previsto no artigo $5^{\circ}, \S 3^{\circ}$ da Carta Magna têm hierarquia superior às leis ordinárias. Na ocasião, 02 (duas) correntes estavam em pauta: a do Ministro Gilmar Mendes, que sustentava o valor supralegal desses tratados, nos seguintes termos:

\footnotetext{
5 "No âmbito dos atos normativos infraconstitucionais, contudo, cabe separar as normas primárias das normas secundárias (Kelsen). Nesse sentido, as normas primárias são aquelas cuja validade tem por fundamento direto a própria Constituição. Chamam-se primárias porque não possuem qualquer vínculo de dependência em face de outro tipo de norma que se situaria num nível intermediário entre elas e as normas constitucionais. De outro lado, as normas infraconstitucionais de natureza secundária consistem naquelas cujo fundamento de validade radica diretamente em alguma norma infraconstitucional primária, e só indiretamente na constitucional. É o caso dos atos regulamentares em geral, como os decretos, portarias, instruções normativas, que retiram validade das leis que regulamentam (...)" (BERNARDES; FERREIRA, 2015, t. II.p. 438).

${ }^{6}$ A Convenção Internacional sobre os Direitos das Pessoas com Deficiência foi o primeiro diploma internacional sobre direitos humanos aprovado nos termos do artigo $5^{\circ}, \S 3^{\circ}$ da Constituição Federal (PLANALTO, 2009).
} 
“(...)Por conseguinte, parece mais consistente a interpretação que atribui a característica de supralegalidade aos tratados e convenções de direitos humanos. Essa tese pugna pelo argumento de que os tratados sobre direitos humanos seriam infraconstitucionais, porém, diante de seu caráter especial em relação aos demais atos normativos internacionais, também seriam dotados de um atributo de supralegalidade.

Em outros termos, os tratados sobre direitos humanos não poderiam afrontar a supremacia da Constituição, mas teriam lugar especial reservado no ordenamento jurídico. Equipará-los à legislação ordinária seria subestimar o seu valor especial no contexto do sistema de proteção dos direitos da pessoa humana.

(...)

Portanto, diante do inequívoco caráter especial dos tratados internacionais que cuidam da proteção dos direitos humanos, não é difícil entender que a sua internalização no ordenamento jurídico, por meio do procedimento de ratificação previsto na Constituição, tem o condão de paralisar a eficácia jurídica de toda e qualquer disciplina normativa infraconstitucional com ela conflitante.

Nesse sentido, é possível concluir que, diante da supremacia da Constituição sobre os atos normativos internacionais, a previsão constitucional da prisão civil do depositário infiel (art. $5^{\circ}$, inciso LXVII) não foi revogada pelo ato de adesão do Brasil ao Pacto Internacional dos Direitos Civis e Políticos (art. 11) e à Convenção Americana sobre Direitos Humanos - Pacto de San José da Costa Rica (art. $7^{\circ}, 7$ ) , mas deixou de ter aplicabilidade diante do efeito paralisante desses tratados em relação à legislação infraconstitucional que disciplina a matéria, incluídos o art. 1.287 do Código Civil de 1916 e o Decreto-Lei n 911, de 1o de outubro de 1969. Tendo em vista o caráter supralegal desses diplomas normativos internacionais, a legislação infraconstitucional posterior que com eles seja conflitante também tem sua eficácia paralisada. É o que ocorre, por exemplo, com o art. 652 do Novo Código Civil (Lei ${ }^{\circ}$ 10.406/2002), que reproduz disposição idêntica ao art. 1.287 do Código Civil de 1916.

Enfim, desde a adesão do Brasil, no ano de 1992, ao Pacto Internacional dos Direitos Civis e Políticos (art. 11) e à Convenção Americana sobre Direitos Humanos - Pacto de San José da Costa Rica (art. $7^{\circ}, 7$ ), não há base legal para aplicação da parte final do art. $5^{\circ}$, inciso LXVII, da Constituição, ou seja, para a prisão civil do depositário infiel.

De qualquer forma, o legislador constitucional não fica impedido de submeter o Pacto Internacional dos Direitos Civis e Políticos e a Convenção Americana sobre Direitos Humanos - Pacto de San José da Costa Rica, além de outros tratados de direitos humanos, ao procedimento especial de aprovação previsto no art. $5^{\circ}, \S$ $3^{\circ}$, da Constituição, tal como definido pela EC n ${ }^{\circ} 45 / 2004$, conferindo-lhes status de emenda constitucional (MENDES, 2008).

E a segunda corrente, capitaneada pelo Ministro Celso de Mello que, a exemplo do

Professor Valério Mazzuoli, inclusive citado em seu voto, conferia status constitucional a tais tratados:

"Reconheço, no entanto, Senhora Presidente, que há expressivas lições
doutrinárias - como aquelas ministradas por ANTÔNIO AUGUSTO CANÇADO
TRINDADE ("Tratado de Direito Internacional dos Direitos Humanos", vol.
1/513, item n. 13, 2a ed., 2003, Fabris), FLÁVIA PIOVESAN ("Direitos Humanos
e o Direito Constitucional Internacional", p. 51/77, 7a ed., 2006, Saraiva), CELSO
LAFER ("A Internacionalização dos Direitos Humanos: Constituição, Racismo e
Relações internacionais", p. 16/18, 2005, Manole) e VALERIO DE OLIVEIRA
MAZZUOLI ("Curso de Direito Internacional Público", p. 682/702, item n. 8, 2a
ed. , 2007, RT), dentre outros eminentes autores - que sustentam, com sólida vol.13, nº.02, RiodeJaneiro, 2020.pp.914-950 
fundamentação teórica, que os tratados internacionais de direitos humanos assumem, na ordem positiva interna brasileira, qualificação constitucional, acentuando, ainda, que as convenções internacionais em matéria de direitos humanos, celebradas pelo Brasil antes do advento da $\mathrm{EC} \mathrm{n}^{\circ} 45 / 2004$, como ocorre com o Pacto de São José da Costa Rica, revestem-se de caráter materialmente constitucional, compondo, sob tal perspectiva, a noção conceitual de bloco de constitucionalidade.

(...)

Após muita reflexão sobre esse tema, e não obstante anteriores julgamentos desta Corte de que participei como Relator (RTJ 174/463-465 - RTJ 179/493-496), inclino-me a acolher essa orientação, que atribui natureza constitucional às convenções internacionais de direitos humanos (...)"(MELLO, 2008).

Por uma votação apertada $(5 \times 4)$ prevaleceu a tese sustentada pelo Ministro Gilmar Mendes, ou seja, de que os tratados internacionais de direitos humanos ratificados e vigentes no Brasil - mas não aprovados com quórum qualificado - possuem status supralegal: estão abaixo da Constituição Federal, mas acima das demais normas infraconstitucionais, ocupando um nível intermediário. O controle de convencionalidade, portanto, equivale ao controle de supralegalidade e refere-se à análise de compatibilidade entre as normas infraconstitucionais e os tratados internacionais de direitos humanos ratificados e em vigor no país, sem, entretanto, terem seguido o procedimento previsto no artigo $5^{\circ}, \S 2^{\circ}$ da Constituição Federal. Tais tratados são, neste sentido, paradigma do controle de convencionalidade, o qual apenas pode ser implementado na via difusa, ou seja, perante qualquer juiz ou tribunal, e de modo concreto, vinculado à uma situação singular e analisado em sede de preliminar, antes da análise do mérito.

A partir dessa decisão do Supremo Tribunal Federal, portanto, a conformação normativa do ordenamento jurídico brasileiro passou a ser analisada sob 03 (três) vertentes distintas. Primeiro aquela relativa ao controle de legalidade que, como dito anteriormente, refere-se à necessária compatibilidade vertical e material que deve existir entre as normas infraconstitucionais de natureza secundária e as normas infraconstitucionais primárias que lhes dão fundamento. Segundo aquela relativa ao controle de convencionalidade (ou de supralegalidade) que, conforme definido pelo Supremo Tribunal Federal, refere-se à compatibilidade vertical e material entre as normas infraconstitucionais (inferiores) e os tratados e convenções internacionais de direitos humanos ratificados e em vigor no país, sem, entretanto,terem sido aprovados pelo quórum qualificado (superiores). Por fim, aquela relativa ao controle de constitucionalidade que tem como parâmetro o bloco de constitucionalidade, ou seja, os padrões normativos com hierarquia equivalente à das normas constitucionais em sentido formal ${ }^{7}$.

7 “(...) B) Constituição formal: conjunto de normas que, independentemente do conteúdo, consideram-se inseridas
em ato escrito no qual se encontram padrões normativos dotados de hierarquia jurídica superior. (...) Nessa vol.13, nº.02, RiodeJaneiro, 2020.pp.914-950 
A adoção pelo Supremo Tribunal Federal de entendimento diverso daquele preconizado pela doutrina, entretanto, não restou imune a críticas. Como esclarece o Professor Ingo Sarlet (2015a):

\begin{abstract}
"Assim, à vista do exposto, enquanto não sobrevenha uma posição uniformizadora, ao que tudo indica, são duas as possibilidades atualmente reconhecidas pelo STF: a) hierarquia (equivalente) de emenda constitucional, no caso dos tratados de direitos humanos incorporados mediante observância do rito estabelecido pelo parágrafo $3^{\circ}$ do artigo $5^{\circ}$ da $\mathrm{CF}$; b) hierarquia supralegal, aplicável aos tratados de direitos humanos ratificados pelo sistema convencional, por meio de Decreto Legislativo aprovado com maioria simples;

Procedendo-se a uma leitura crítica da posição do STF há que enfatizar que a condição de direitos fundamentais é absolutamente incompatível com uma hierarquia normativa infraconstitucional, visto que - de acordo com o que buscamos demonstrar nas colunas anteriores - direitos fundamentais são sempre direitos constitucionais e não podem estar à disposição plena do legislador ordinário.

Entendimento diverso, mesmo em que seja em favor de uma hierarquia supralegal dos tratados (posição hoje adotada pelo Supremo Tribunal Federal na matéria!), ainda que tenha representado um considerável avanço em relação ao entendimento antes prevalente (que consagrava a paridade entre lei ordinária e tratado) segue relegando os direitos humanos consagrados nos tratados internacionais a uma posição secundária em face dos direitos fundamentais da Constituição, sendo, de tal sorte, no mínimo questionável, visto que o STF, como bem apontado também por ValerioMazzuoli, acabou (em matéria de tratados de direitos humanos) criando uma "duplicidade de regimes jurídicos".
\end{abstract}

Não obstante os estudos e críticas doutrinárias, fato é que o Supremo Tribunal Federal, ao estabelecer que os tratados e convenções internacionais de direitos humanos ratificados e em vigor no Brasil, porém, internalizados sem seguir o rito previsto no artigo $5^{\circ}, \S 3^{\circ}$ da Constituição Federal, seriam normas supralegais não só inovou na pirâmide normativa de Kelsen como deu corpo ao controle deconvencionalidade (ou de supralegalidade), consistente na aferição de compatibilidade material e vertical entre as normas infraconstitucionais e a norma supralegal, a ser implementado unicamente na via difusa, como preliminar à análise do caso concreto.

acepção, configuram normas formalmente constitucionais: a) em sentido estrito, as normas implícita ou explicitamente extraídas de documento normativo escrito e solene, ao qual se atribui hierarquia superior em relação às demais normas do mesmo sistema normativo (constituição formal); e b) em sentido amplo, todas as normas dotadas de hierarquia normativa superior, incluindo as extraídas de fontes diversas da constituição formal propriamente dita, tais como as normas constantes das emendas constitucionais. (...)O controle de constitucionalidade tem por fundamento teórico a defesa do princípio da supremacia constitucional (...). A partir do momento que se atribuem às normas constitucionais hierarquia normativa superior, é necessário garantir que os atos contrários à constituição não produzam os mesmos efeitos que normalmente produziriam, sob pena de converter a supremacia da constituição em simples instrumento de retórica. (...) A doutrina majoritária, contudo, só estabelece relações entre o controle de constitucionalidade de atos normativos e a supremacia constitucional do tipo formal (BERNARDES; FERREIRA, t. I.p. 77 e 315). 


\section{O DIREITO PENAL.}

\subsection{CONCEITO.}

A conceituação de uma disciplina tão complexa quanto o Direito Penal não é tarefa fácil. Não obstante, há uma certa concordância doutrinária no sentido de que o Direito Penal se presta, por um lado, à proteção dos bens mais caros à sociedade e, por outro, à limitação do poder punitivo do Estado (GRECO, 2015, p. 33; NUCCI, 2011, p. 67).

De fato, incumbe a norma penal, assim como a qualquer outra norma jurídica, uma função eminentemente protetora. No caso, compete especificamente ao Direito Penal, conforme aduz a doutrina majoritária (OLIVÉ et al., 2017, p. 75), a proteção de bens jurídicos.

Neste sentido, cabe ao Direito Penal garantir aos cidadãos uma convivência pacífica e harmoniosa, função esta que decorre da própria Constituição e, principalmente, do fato de que o Brasil se constitui em um Estado Democrático de Direito ( $\mathrm{CF}$, art. $\left.1^{\circ}\right)$. Em verdade, desde o Iluminismo, vigora a ideia de contrato social, ou seja, de que o povo, detentor do poder, constitui um governo estatal e lhe transfere o monopólio desse poder. Entretanto, essa transferência se dá apenas na medida necessária para garantir a liberdade e segurança das pessoas. É em razão disso, por exemplo, que a vedação à liberdade de expressão é considerada abusiva. Afinal, não se afigura necessária à manutenção da segurança ou mesmo da liberdade (ROXIN, 2017, p. 51)

Por outro lado, as condições essenciais à convivência pacífica e harmoniosa entre as pessoas são exatamente o que se convencionou chamar de "bens jurídicos", como a vida, a integridade corporal, a autonomia sexual, o patrimônio, e os chamados bens públicos, como a moeda, a administração da justiça, entre outros (ROXIN, 2017, p. 51).

Cumpre ressaltar que o Direito Penal não protege qualquer bem jurídico, mas apenas aqueles essenciais à convivência humana, ou seja, os mais caros à sociedade. E o faz motivando as pessoas a que não pratiquem os comportamentos tidos como lesivos a tais bens, sob ameaça de pena. Portanto, ao lado da função protetora do Direito Penal encontra-se a função motivadora. De fato,

“1. O Direito Penal não é só um instrumento de proteção de bens jurídicos (também o serviço de bombeiros ou a cruz vermelha o são), sim um instrumento de motivação do comportamento humano em sociedade. Para conseguir a proteção de bens jurídicos que a norma penal persegue, se desencadeiam nos indivíduos determinados processos psicológicos que os induzem a respeitar ditos bens jurídicos. 
(...) O principal meio de coação jurídica, a pena, serve, pois, para motivar comportamentos nos indivíduos. A norma penal cumpre, portanto, essa função motivadora que assinalávamos a princípio, ameaçando com uma pena a realização de determinados comportamentos, considerados pelas autoridades de uma sociedade como não desejáveis" (CONDE; ARÁN, 2010, p. 61-62, tradução livre).

Se, por um lado, tem-se que a função protetiva do Direito Penal consiste na proteção dos bens jurídicos essenciais, o que, evidentemente, determina quais comportamentos podem ser tipificados pelo Estado (de fato, o legislador apenas pode tipificar o comportamento que lesione ou, ao menos, exponha a perigo de lesão bens jurídicos tidos por essenciais na sociedade em que atua), por outro, tem-se que a função motivadora se dá a partir da imposição de uma pena. Não obstante, cumpre determinar quais efeitos devem surtir essa pena para que se alcance a missão do Direito Penal.

Como dito, o Brasil se constitui num Estado Democrático de Direito e, nesse modelo de Estado, as leis penais apenas estão justificadas quando tendem à proteção da liberdade individual e à ordem social que está em vigência. Assim, também a pena concreta deve perseguir tais objetivos, o que somente é possível se for considerado o fim preventivo, ou seja, uma perspectiva para o futuro.

Neste ponto, vale destacar que a prevenção geral (em seus aspectos positivo- relativa à ideia de que a norma penal serve para reforçar a consciência jurídica dos cidadãos de que a norma está vigorando e, em consequência, da disposição em cumprir as referidas normas -,e negativo-relativo à ideia de que a norma penal serve para intimidar o sujeito para que se comporte, não cometendo delitos) e a prevenção especial (aqui, tomada apenas em seu aspecto positivo, ou seja, que busca a reintegração ou reinserção social do criminoso) devem figurar conjuntamente como fins da pena (ROXIN, 2008, t. I, p. 95-98; OLIVÉ et al., 2017, p. 210$214)^{8}$, havendo uma ponderação diferenciada de tais finalidades nos três sucessivos momentos do processo de aplicação do Direito Penal: ameaça (momento legislativo), imposição (momento judicial) e execução (momento executivo).

\footnotetext{
${ }^{8}$ Em sentido contrário Eugênio RaúlZaffaroni e José Henrique Pierangeli, para os quais a prevenção especial da pena é o único objetivo da pena, sendo que rechaçam a prevenção geral, sob o argumento de que sua adoção conduziria, em última análise, à aceitação da vingança. Em suas palavras: "A prevenção geral se funda em mecanismos inconscientes: o homem, respeitador do direito sente que reprimiu tendências que o outro não reprimiu; que privou-se do que o outro não se privou, e experimenta inconscientemente como inútil o sacrifício de uma privação a que o outro não se submeteu. Inconscientemente, quem se reprimiu clama por vingança, e daí que o passo da prevenção geral à vingança nunca seja de todo claro e que a prevenção geral sempre encerre um conteúdo vingativo. Para refrear este conteúdo vingativo se sustenta que a pena "justa" é a retributiva", e por isto, dentro desta linha, deve obedecer à lei do talião: a pena deve importar a mesma quantidade de mal causado pelo delito ("olho por olho, dente por dente") (2011, vol. 1, p. 99).
} 
No momento legislativo, ou seja, de criação da lei (tipos penais e pena in abstrato)o legislador deve ter em conta a prevenção geral negativa, pois, com a elaboração da norma penal, comunica-se aos membros da comunidade quais comportamentos são tidos como intoleráveis e como se reagirá ante a sua ocorrência. Há, portanto, uma ameaça concreta de imposição de uma pena, cuja intenção é dissuadir os membros da comunidade de praticarem delitos. Não obstante, também deve-se ter em conta a prevenção geral positiva, pois a ameaça de pena cumpre o papel de reforçar a consciência jurídica do cidadão na proteção de bens jurídicos e em sua disposição em cumprir as normas. Por fim, verifica-se, ainda que em segundo plano, a prevenção especial positiva, vez que a ameaça penal não pode ser desmedida a ponto de impossibilitar a reinserção social do acusado.

Já no momento judicial, o Magistrado, ao proferir sentença condenatória e impor a pena, deve observar a prevenção especial positiva que, sem dúvida, é o principal fim da pena neste momento. O juiz, ao impor a pena, deve - observando os preceitos legais - eleger a pena que melhor se adeque ao caso concreto e fixá-la em patamar adequado à reintegração social do acusado. Não obstante, também se verifica a prevenção geral positiva neste momento, pois, subsidiariamente, com a imposição da pena no caso concreto, deve haver a reafirmação da consciência social da norma, ou seja, a aplicação da pena deve demonstrar à sociedade que a norma continua em vigência, reafirmando os valores da sociedade afrontados com a prática delitiva.

Por fim, no momento de execução da pena deve prevalecer a prevenção especial positiva, ou seja, o fim de reintegração do condenado à sociedade. A execução da pena deve pautar-se pela dignidade humana e pelos direitos fundamentais, buscando sempre a reintegração ou reinserção social. Não se descarta, por completo, os fins preventivos gerais, porquanto a imposição da pena, na sentença condenatória, apenas restabelece a confiança social no ordenamento jurídico se referida sentença for realmente executada(OLIVÉ et al., 2017, p. 212214).

Como se pode observar, portanto, a função primordial do Direito Penal é a proteção dos bens jurídicos mais caros à sociedade, o que apenas pode ser levado a cabo através da motivação de todos os cidadãos de que se abstenham de cometer delitos. E essa motivação se dá através da ameaça de imposição de uma pena que, num Estado Democrático de Direito, somente pode ter por finalidade a prevenção de crimes. Trata-se, em verdade, da exteriorização do poder de punir do Estado, o qual, evidentemente, num modelo democrático, como o adotado pela Carta Magna brasileira, não supõe um emprego arbitrário ou abusivo, mas antes a existência de limites 
fixados com grande precisão. E é justamente por isso que se diz que o Direito Penal se presta não só à proteção dos bens mais caros à sociedade, mas também à limitação do poder punitivo do Estado, o que o faz através de princípios valorativos, como se verá a seguir.

\subsection{PRINCÍPIOS BASILARES.}

Como visto anteriormente, o poder punitivo do Estado deve estar submetido a controles e restrições que impeçam arbitrariedades, abusos e até mesmo erros judiciais. Tratando o Direito Penal de um instrumento de controle social através do qual se exterioriza o jus puniendi estatal, tem-se que este controle deve ser realizado nos limites necessários à garantia de uma convivência pacífica e harmoniosa aos cidadãos, ou seja, na exata medida exigida para a proteção de bens jurídicos. Todo o mais será considerado abuso, excesso, a acarretar a responsabilização dos agentes públicos que assim atuarem.

Os limites materiais ao exercício do poder punitivo do Estado se constituem em princípios valorativos que norteiam todo o sistema penal. São eles o princípio da legalidade, o princípio da ofensividade, o princípio da intervenção mínima, o princípio do non bis idem e o princípio da culpabilidade, a seguir delineados.

\subsubsection{PRINCÍPIO DA LEGALIDADE.}

O princípio da legalidade refere-se à máxima latina nullumcrimen, nullapoenasine lege, ou seja, à ideia de que não se pode sancionar com uma pena uma conduta que não esteja previamente proibida por lei.

A origem do princípio remonta à Carta Magna Inglesa de 1215, segundo a qual nenhum homem livre poderia ser preso ou privado de sua propriedade, a não ser pela Lei da Terra (JUNQUEIRA; VANZOLINI, 2013, p. 32). Não obstante, foi com o Iluminismo que o postulado ganhou corpo e validade. Nas palavras de Beccaria (2005, p. 44), "só as leis podem decretar as penas dos delitos, e esta autoridade só pode residir no legislador, que representa toda a sociedade unida por um contrato social"".

Inspirada nos pensamentos iluministas e resultado da Revolução Francesa, a Declaração dos Direitos do Homem e do Cidadão de 1789 incorporou o princípio da legalidade em seu

\footnotetext{
${ }^{9}$ O livro "Dos delitos e das penas" foi publicado originalmente na cidade italiana de Milão em 1764. A obra é uma das inauguradoras do humanismo iluminista do século XVIII.
} 
artigo $8^{\circ}$, dispondo que "a lei apenas deve estabelecer penas estrita e evidentemente necessárias e ninguém pode ser punido senão por força de uma lei estabelecida e promulgada antes do delito e legalmente aplicada".

O postulado da legalidade também consta na Declaração Universal dos Direitos Humanos das Nações Unidas de 1948 (art. 11.2) e na Convenção Americana de Direitos Humanos de 1969 (Pacto de São José da Costa Rica, art. 9º).

No Brasil, o Código Penal, cuja parte geral foi dada pela Lei 7.209/1984, estabelece logo em seu artigo $1^{\circ}$ que não há crime sem lei anterior que o defina e que não há pena sem prévia cominação legal. A Constituição Federal de 1988, por sua vez, utilizando os mesmos termos, consagra o princípio da legalidade em seu artigo $5^{\circ}$, inciso XXXIX.

Em verdade, o princípio da legalidade encerra 02 (duas) máximas. A primeira refere-se à impossibilidade de haver delito sem lei anterior. Segundo Roxin (2008, t. I, p. 137), por mais que uma conduta seja em alto grau socialmente nociva e reveladora de necessidade de pena, o Estado só poderá tomá-la como motivo para a imposição de uma sanção jurídico penal se antes tiver advertido expressamente na lei que tal conduta era proibida.

A segunda máxima refere-se à impossibilidade de haver uma pena sem lei. Conforme explica o autor mencionado, além da circunstância de que uma determinada conduta esteja prevista na lei como punível, também a classe de pena que poderá ser imposta e sua possível quantia devem estar legalmente fixadas antes do fato (ROXIN, 2008, t. I, p. 138).

O princípio da legalidade, portanto, afigura-se como pedra angular do Direito Penal, sendo imprescindível não só para o Estado, como limitadora de seu poder de punir, mas também aos cidadãos, destinatários das normas incriminadoras. Agora, não basta a existência formal da lei, até porque muitos regimes autoritários contavam com a existência de leis escritas. Além da promulgação formal da lei, deve-se atentar ao conteúdo do princípio da legalidade, o qual, tradicionalmente, apresenta 04 (quatro) repercussões: a proibição da analogia, a proibição do direito consuetudinário para fundamentar e agravar a pena, a proibição da retroatividade e a proibição de leis penais indeterminadas ou imprecisas, sendo as 02 (duas) primeiras dirigidas ao juiz e as 02 (duas) últimas ao legislador (ROXIN, 2008, t. I, p. 140).

A proibição da analogia refere-se à máximanullumcrimen, nullapoenasine lege strictae refere-se à impossibilidade de se aplicar a analogia para ampliar os limites do Direito Penal. Com efeito, a analogia configura forma de integração do ordenamento jurídico, consistente na aplicação de uma norma existente a um caso semelhante, em relação ao qual haja uma lacuna legal. Divide-se em analogia in malam partem, quando agrava a situação do acusado, e analogia 
in bonam partem, quando de qualquer forma beneficia ou favorece o agente(JUNQUEIRA; VANZOLINI, 2013, p. 35). A ideia de que deve existir lei prévia, a fim de possibilitar que todos tenham conhecimento de quais comportamentos são proibidos, sob ameaça de pena, impede a aplicação da analogia para prejudicar o réu. Não obstante, por razões de equidade, nada impede sua aplicação em benefício do agente.

Quanto à proibição do direito consuetudinário para fundamentar e para agravar a pena, verifica-se que tal desdobramento se refere à máxima nullumcrimen, nullumpoenasine lege scripta, ou seja, à ideia de reserva legal. Somente a lei escrita pode criar delitos e penas. O direito consuetudinário, isto é, baseado em costumes, no direito não escrito, não se presta a fundamentar ou agravar a punibilidade, a qual apenas poderá ser determinada legalmente.

A proibição da retroatividade (nullumcrimen, nullapoenasine lege praevia) é outro dos desdobramentos do princípio da legalidade. Exige-se a existência de uma lei prévia para se poder aplicar a pena. As leis penais não são criadas para alcançarem fatos passados, mas tão somente para atingir o futuro. Ademais, o princípio da irretroatividade, como também é conhecido, permite a vigência da função motivadora do Direito Penal, pois não é possível motivar o sujeito se ele não conhece a norma. Em verdade, a norma precisa existir para exercer seu papel de motivação.

Cumpre ressaltar, ainda, que se proíbe apenas a retroatividade que for desfavorável ao réu. Assim, a Constituição Federal, em seu artigo $5^{\circ}$, inciso XL, dispõe que "a lei penal não retroagirá, salvo para beneficiar o réu". No mesmo sentido, dispõe o Código Penal, em seu artigo $2^{\circ}$, que "ninguém pode ser punido por fato que lei posterior deixa de considerar crime, cessando em virtude dela a execução e os efeitos penais da sentença condenatória", acrescentando, no parágrafo único, que "a lei posterior, que de qualquer modo favorecer o agente, aplica-se aos fatos anteriores, ainda que decididos por sentença condenatória transitada em julgado".

Por fim, quanto à proibição de leis penais indeterminadas ou imprecisas, tem-se a aplicação da máxima nullumcrimen, nullapoenasine lege certa, também conhecida como princípio da taxatividade, o qual, por um lado, exige uma formulação precisa dos preceitos penais e, por outro, proíbe incriminações vagas e indeterminadas. 


\subsubsection{PRINCÍPIO DA OFENSIVIDADE.}

Como demonstrado ao longo deste ensaio, a função primordial do Direito Penal é a proteção dos bens jurídicos mais valiosos à sociedade. Assim sendo, somente será possível a imposição de uma pena se constatada ofensa ou perigo de ofensa a um bem jurídico penalmente protegido.

Com efeito, o princípio da ofensividade, também conhecido por princípio da lesividade (nullumcrimensine injuria), impede que ataques desprovidos de qualquer idoneidade lesiva, mesmo que dirigidos a importantes bens jurídicos, sejam penalmente sancionados (por exemplo, o crime impossível - art. 17, CP).

A teoria do bem jurídico, portanto, manifesta um fundamento à intervenção penal, pois todo delito requer, para sua configuração, a lesão ou colocação em perigo de um bem jurídico (OLIVÉ et al., 2017, p. 93).

\subsubsection{INTERVENÇÃO MÍNIMA.}

Também conhecido como princípio da subsidiariedade ou ultimaratio, o princípio em comento diz respeito à possibilidade de proteção dos bens jurídicos por meios menos gravosos que a sanção penal. Com efeito, o Direito Penal deixa de ser necessário se a proteção que dele se espera puder ser conseguida por outros meios menos lesivos aos direitos individuais.

Como desdobramento do princípio da intervenção mínima, encontra-se o princípio da fragmentariedade. De fato, uma vez decidido que determinado bem jurídico necessita de proteção do Direito Penal, terá de se decidir em quais hipóteses terá de ser acionado tal mecanismo de controle. Somente as agressões mais intoleráveis ao bem jurídico devem ser proibidas. Em alguns casos, por exemplo, bastará a proibição da conduta dolosa. Em outros, entretanto, sancionam-se comportamentos dolosos e culposos (OLIVÉ et al., 2017, p. 95).

Assim, nem todas as ações que atacam bens jurídicos são proibidas pelo Direito Penal, nem mesmo todos os bens jurídicos são protegidos por ele. O Direito Penal limita-se a punir tão somente as ações mais graves contra os bens jurídicos mais importantes, estando, neste ponto, seu caráter fragmentário. 


\subsubsection{PRINCÍPIO DO NON BIS IN IDEM.}

O princípio do non bis idem refere-se à impossibilidade de se punir 02 (duas) vezes a mesma pessoa pela prática do mesmo fato.

Conforme consta no Pacto Internacional de Direitos Civis e Políticos das Nações Unidas, "ninguém poderá ser processado ou punido por um delito pelo qual já foi absolvido ou condenado por sentença passada em julgado, em conformidade com a lei e os procedimentos penais de cada país" (artigo 14, item 7). No mesmo sentido, dispõe o Pacto de São José da Costa Rica ao consignar que "o acusado absolvido por sentença passada em julgado não poderá se submetido a novo processo pelos mesmos fatos" (artigo $8^{\circ}$, item 4 ).

Como se pode observar, o princípio em comento apresenta um aspecto substantivo, que significa justamente que ninguém pode ser castigado mais de uma vez pela prática da mesma conduta, e um aspecto processual, que impede que a pessoa seja processada e julgada mais de uma vez pelo mesmo fato.

Por fim, para que haja a incidência do princípio do non bis in idem, explica a doutrina(OLIVÉ et al., 2017, p. 96), é necessário que se trate da mesma pessoa (identidade pessoal - eadem persona), do mesmo objeto (eadem res) e de idêntica causa de persecução (eadem causa petendi).

\subsubsection{PRINCÍPIO DA CULPABILIDADE.}

O princípio da culpabilidade refere-se à máxima nullapoenasine culpa e é entendido pela doutrina (CONDE; ARÁN, 2010, p. 92-93; JUNQUEIRA; VANZOLINI,2013, p 69-70) sob 03 (três) aspectos distintos.

O primeiro refere-se ao que se convencionou chamar de princípio de responsabilidade subjetiva, ou seja, a ideia de que para haver responsabilização penal é necessário que a pessoa tenha agido com dolo ou, no mínimo, com culpa. Repudia-se, portanto, a responsabilidade objetiva, que deriva unicamente da associação causal entre uma conduta e um resultado, ou seja, sem que haja um nexo subjetivo.

O segundo aspecto refere-se à culpabilidade como elemento da teoria do delito. Aqui, a culpabilidade serve de fundamento à pena, porquanto apenas será possível reprovar o sujeito, impondo-lhe uma pena, caso pudesse ter agido de outro modo. Em outras palavras, se busca saber se é possível impor uma pena ao sujeito que praticou fato típico e antijurídico ou se ele 
agiu acobertado por alguma excludente de culpabilidade (ex. inimputabilidade, inexigência de conduta diversa, etc.).

O terceiro e último enfoque diz respeito à culpabilidade como elemento de determinação e medição da pena. Refere-se à deliberação da espécie e quantidade de pena e até mesmo do regime prisional. No ordenamento jurídico brasileiro, tal acepção da culpabilidade encontra-se expressa no Código Penal, por exemplo, no artigo $33, \S 3^{\circ}$, ao tratar do regime prisional a ser fixado em concreto; no artigo 44, inciso III, ao estabelecer os requisitos necessários para a substituição da pena privativa de liberdade por restritiva de direitos; no artigo 59, ao disciplinar os critérios de fixação da pena base; e no artigo 77, inciso II, ao discorrer sobre os requisitos necessários para a suspensão da execução da pena carcerária. A culpabilidade é, pois, forma de se limitar, ou melhor, de se adequar a pena imposta ao concreto.

Por fim, há ainda quem apresente o princípio da personalidade (ou intranscendência) das penas como vertente do princípio da culpabilidade. Neste aspecto, verifica-se que a responsabilidade penal deve ficar restrita aos autores e partícipes do delito, não podendo transpassar à família, por exemplo.

Neste sentido, inclusive, dispõe o Pacto de São José da Costa Rica que "a pena não pode passar da pessoa do delinquente" (art. 5, 3 ). Na mesma linha, estabelece a Carta Magna de 1988, em seu artigo $5^{\circ}$, inciso XLV, ou seja, como garantia fundamental, que "nenhuma pena passará da pessoa do condenado, podendo a obrigação de reparar o dano e a decretação do perdimento de bens ser, nos termos da lei, estendidas aos sucessores e contra eles executadas, até o limite do valor do patrimônio transferido".

\section{A APLICABILIDADE DO CONTROLE DE CONVENCIONALIDADE AO DIREITO PENAL BRASILEIRO.}

Como visto no início deste ensaio, o controle de convencionalidade (ou de supralegalidade), nos termos definidos pelo Supremo Tribunal Federal, refere-se ao mecanismo destinado a solucionar eventual antinomia entre tratados e convenções internacionais de direitos humanos ratificados e em vigor no país, porém,sem seguir o rito previsto no artigo $5^{\circ}, \S 3^{\circ}$ da Constituição Federal e algum ato normativo que lhe seja desconforme.

Em verdade, deve o julgador, antes de adentrar ao mérito, analisar a compatibilidade entre a lei ordinária mencionada nos autos, por exemplo, e a norma supralegal, no caso o tratado ou convenção internacional sobre direitos humanos em vigor no país, porém sem ter sido 
aprovado conforme quórum qualificado estabelecido no artigo acima mencionado, afastando o primeiro ato normativo se incompatível com o segundo (eficácia paralisante do tratado em relação à legislação infraconstitucional que disciplina a matéria).

O controle de convencionalidade, conforme o Excelso Pretório, é implementado na via difusa, ou seja, por qualquer juiz e como matéria preliminar. Em outras palavras, todo juiz tem competência para aferir a convencionalidade de uma lei, inclusive se tal lei veicular matéria penal.

Neste ponto, cumpre consignar que após as atrocidades cometidas durante as 02 (duas) grandes guerras mundiais, a comunidade internacional buscou impor diretrizes e normas aos mais diversos países, no sentido de garantir a dignidade humana, classificando-a como valor supremo de todas as nações. Neste sentido, por exemplo, destaca-se o Estatuto de Roma, o qual criou uma corte penal internacional permanente, com jurisdição sobre as pessoas responsáveis por crimes internacionais de maior gravidade, tendo sido especificados esses como sendo os de genocídio, contra a humanidade, de guerra e agressão. Não bastasse, há uma farta gama de convenções que buscam, sobretudo, proteger os grupos historicamente reconhecidos como vulneráveis, como os negros, deficientes físicos e mentais, mulheres e presos. Em verdade, em se tratando de direito penal, há uma variedade de tratados abordando os mais diversos temas, na tentativa de se conter os abusos cometidos principalmente em estados autoritários e também contra os grupos vulneráveis.

Não obstante, o Código Penal pátrio data de 1940, sendo a parte geral, fruto de reforma operada em 1984. Por outro lado, a legislação internacional é bem mais recente e, em muitos aspectos, mais moderna e preocupada em garantir direitos não só individuais e também coletivos, o que, evidentemente, pode conflitar com o ordenamento interno.

Ocorre que o Direito Penal, justamente por se tratar de um instrumento de controle social através do qual se exterioriza o jus puniendi estatal, está cercado de limites. Com efeito, o controle realizado pelo Direito Penal encontra-se limitado ao necessário à garantia de uma convivência pacífica e harmoniosa aos cidadãos, ou seja, ao necessário à proteção dos bens jurídicos mais caros à sociedade. E isto ocorre porque o Direito Penal impõe as sanções mais duras aos comportamentos mais gravosos praticados pelo homem. Através do Direito Penal, o cidadão pode perder sua liberdade de locomoção, direito fundamental previsto na Carta Magna (art. $5^{\circ}$, caput e inciso XI) e por ela protegido com a previsão do habeas corpus (art. $5^{\circ}$, LXVIII). Assim, por um lado, se existea possibilidade dehaverconflitos entre o Código Penal brasileiro e tratados e convenções internacionais (o Código Penal foi recepcionado pela 
Constituição Federal de 1988 com o status de lei ordinária e, portanto, pode ser objeto do controle de convencionalidade), por outro, deve-se reconhecer que o Direito Penal, ao mesmo tempo que exterioriza o poder punitivo doEstado, também o limita, fazendo-o através de princípios valorativos que regem todo o sistema penal.

O que se pretende demonstrar é que o controle de convencionalidade não pode resultar, por exemplo, na incriminação de um cidadão, porquanto o sistema penal brasileiro é regido pelo princípio da legalidade. Também não pode resultar em aplicação retroativa de lei que prejudique o acusado. Aliás, tanto no caso do princípio da legalidade quanto no da irretroatividade da lei penal mais gravosa, verifica-se a previsão de tais postulados na Constituição Federal de 1988 e, como já mencionado neste ensaio, o controle de convencionalidade tem como parâmetro a norma supralegal que, conforme assentou o Supremo Tribunal Federal, encontra-se abaixo da Carta Magna e acima das normas infraconstitucionais, numa posição intermediária.

Em verdade, todos os princípios que fundamentam o sistema penal podem ser extraídos da Constituição Federal, seja diretamente, através da existência de norma constitucional expressa, seja indiretamente, através de uma interpretação teleológica.

Com efeito, a interpretação que mais se coaduna com o Estado Democrático de Direito é aquela que entende o Direito Penal como limitador do jus puniendi estatal, ou seja, que entende que o Direito Penal deve estar de acordo com a Carta Magna vigente e com os ideias democráticos que dela advém.

Neste sentido, inclusive, decidiu o Supremo Tribunal Federal ao julgar o Pedido de Extradição 1362, em 09 de novembro de 2016. Tratava-se, na espécie, de pedido formulado pelo Governo da Argentina de extradição do Sr. Salvador Siciliano, sob o argumento de que o extraditando teria praticado delitos equivalentes ao de associação criminosa (art. 288 do Código Penal), durante os anos de 1973 a 1975, e, no ano de 1974, crimes equivalentes aos de sequestro qualificado (art. 148, § $2^{\circ}$, do Código Penal) e de homicídio qualificado (art. 121, § $2^{\circ}$, do Código Penal). Argumentava o requerente que os delitos não estariam prescritos por se tratarem de crimes de "lesa-humanidade" (também chamados de crimes contra a humanidade).

Ademais, o próprio Estatuto de Roma, em seu artigo 29, dispõe que os crimes de competência daquele Tribunal não prescrevem. 
Ocorre que o requisito básico para que haja a extradição é a existência de duplapunibilidade ${ }^{10}$, ou seja, que a conduta que será punida no exterior também seja considerada crime no Brasil e possa aqui ser punida. E justamente em razão disso era necessário saber, naquele caso, se os crimes imputados pelo Governo Argentino ao extraditando estavam ou não prescritos (pelo ordenamento jurídico interno, estavam ${ }^{11}$; pelo Estatuto de Roma, não ${ }^{12}$ ).

Em votação apertada (6x5), prevaleceu o voto do Ministro Teori Zavascki, designado para redigir o acórdão, o qual entendeu que a circunstância de o Estado requerente ter qualificado os delitos imputados ao extraditando como de lesa-humanidade não afasta a orientação de que, no Brasil, não se aplica a tese de imprescritibilidade dos crimes contra a humanidade. E o Ministro assim procedeu baseando-se em 02 (dois) argumentos.

O primeiro refere-se ao fato de que o Brasil não subscreveu a Convenção sobre a Imprescritibilidade dos Crimes de Guerra e dos Crimes contra a Humanidade, nem aderiu a ela. Com efeito, a referida convenção, adotada pela Resolução 2391 da ONU, prevê que os delitos de lesa-humanidade devem ser submetidos à jurisdição universal e declarados imprescritíveis. Por força desta Resolução, nos termos de seu artigo $3^{\circ}$, os Estados Membros obrigam-se a adotar todas as medidas internas, de ordem legislativa ou outra, que sejam necessárias a fim de permitir a extradição. Ocorre que esta resolução não foi ratificada pelo Estado brasileiro.

Poder-se-ia argumentar, entretanto, que a Corte Interamericana de Direitos Humanos já decidiu, em diversas oportunidades ${ }^{13}$, que os Estados integrantes do sistema interamericano de direitos humanos (dentre eles, o Brasil) deverão reconhecer a imprescritibilidade dos crimes de lesa-humanidade e punir os suspeitos de sua prática. Não obstante, as decisões da Corte, que tem função jurisdicional, só têm força vinculante entre as partes e nenhuma das referidas decisões tinha o Brasil como parte. Já a Comissão Interamericana de Direitos Humanos, que possui o mesmo entendimento da Corte, não possuifunção jurisdicional e, portanto, suas recomendações não possuem força vinculante ${ }^{14}$. Assim, tem-se que o Brasil não se obrigou

\footnotetext{
${ }^{10}$ Conforme pacífica jurisprudência do Supremo Tribunal Federal, “a satisfação da exigência concernente à dupla punibilidade constitui requisito essencial ao deferimento do pedido extradicional" (Ext 683, Relator(a): Min. CELSO DE MELLO, Tribunal Pleno, Dje de 21.11.2008).

11 Todos os delitos encontravam-se prescritos, porquanto, desde a consumação havia transcorrido tempo muito superior ao prazo prescricional máximo previsto no Código Penal, equivalente a 20 (vinte) anos (art. 109, I). Não constava dos autos, ademais, a existência de qualquer das causas interruptivas da prescrição.

12 Pelo Estatuto de Roma, os crimes imputados ao extraditando são considerados imprescritíveis.

13 Nesse sentido: Caso Barrios Altos versus Peru, mérito, sentença de 14 de março de 2001, par. 41; Caso La Cantuta, mérito, sentença de 29 de novembro de 2006, par. 152; e Caso Do Massacre de Las Dos Erres, sentença de 24 de novembro de 2009, par. 129 (CAVALCANTE, 2018).

${ }^{14}$ Neste sentido: “(...) as funções da Comissão Interamericana de Direitos Humanos são quase judiciais. A maior 'punição' consiste na publicação de suas opiniões e conclusões sobre as questões a ela submetidas na forma de relatório (Artigo 51, parágrafo $3^{\circ}$ ) (...). Ela não prolata sentenças. A função jurisdicional dentro do sistema
} vol.13,nº.02, RiodeJaneiro, 2020.pp.914-950 
juridicamente a reconhecer a imprescritibilidade dos crimes de lesa-humanidade, quer em sua esfera doméstica, quer no plano internacional.

O segundo argumento refere-se justamente ao fato de que a prescrição é instituto de direito material(BITENCOURT, 2015, p. 889) e, portanto, submete-se ao princípio constitucional da legalidade. De fato, apenas lei interna pode dispor sobre prescritibilidade ou imprescritibilidade da pretensão estatal de punir. Sobre o tema, explicou o Ministro Teoria Zavascki, reportando-se a trecho do voto do Ministro Celso de Mello exarado por ocasião do julgamento da ADPF 153, que:

\begin{abstract}
"Ninguém pode ignorar que, em matéria penal, prevalece, sempre, o postulado da reserva constitucional de lei em sentido formal.

Esse princípio, além de consagrado em nosso ordenamento positivo $\left(\mathrm{CF}\right.$, art. $5^{\circ}$, XXXIX), também encontra expresso reconhecimento na Convenção Americana de Direitos Humanos (Artigo $9^{\circ}$ ) e no Pacto Internacional sobre Direitos Civis e Políticos (Artigo 15), que representam atos de direito internacional público a que o Brasil efetivamente aderiu.

(...) Isso significa, portanto, que somente lei interna (e não convenção internacional, muito menos aquela sequer subscrita pelo Brasil) pode qualificarse, constitucionalmente, como a única fonte formal direta, legitimadora da regulação normativa concernente à prescritibilidade ou à imprescritibilidade da pretensão estatal de punir, ressalvadas, por óbvio, cláusulas constitucionais em sentido diverso, como aquelas inscritas nos incisos XLII e XLIV do art. $5^{\circ}$ de nossa Lei Fundamental".
\end{abstract}

Assim, ainda que houvesse norma de direito internacional de caráter cogente ou ratificada pelo Brasil que estabelecesse a imprescritibilidade dos crimes contra a humanidade, tal norma não encontraria aplicabilidade no ordenamento jurídico brasileiro. Isso porque, para que aqui pudesse valer, seria necessário que houvesse uma lei interna em sentido formal, em atenção ao postulado constitucional da legalidade.

Não bastasse, o Ministro Teori Zavascki (Pedido de Extradição 1362/DF, 2016, p. 93 94), fez questão de esclarecer que "ainda que considerado o Estatuto de Roma como norma supralegal, ou mesmo de estatura constitucional, ele não elidiria a força normativa do art. $5^{\circ}$, $\mathrm{XV}$, da Constituição da República, segundo o qual 'a lei penal não retroagirá, salvo para beneficiar o réu"”. Afinal, os delitos informados pelo Governo Argentino datam da década de 1970 e o Estatuto de Roma é posterior, não podendo, portanto, retroagir para prejudicar o réu.

Como se pode observar, o controle de convencionalidade (ou supralegalidade) não pode resultar em inobservância dos princípios fundamentais do Direito Penal, justamente por serem limitadores do jus puniendi. No caso antes descrito, o Plenário do Supremo Tribunal Federal

interamericano cabe, para os Estados que a aceitam, à Corte Interamericana de Direitos Humanos, tratada no Capítulo Oitavo do Pacto de São José” (ALVES, 1997. p. 281-282). 
acabou por negar a extradição pleiteada, não obstante ter o Brasil incorporado ao ordenamento interno o Estatuto de Roma, justamente por faltar o requisito da dupla punibilidade. Embora puníveis na Argentina, os crimes imputados não o eram no Brasil porque fulminados pela prescrição que, por tratar-se de instituto de direito material, submete-se aos princípios fundantes do Direito Penal. O acórdão do Pedido de Extradição 1362/DF, então,restou assim ementado:

1. Conforme pacífica jurisprudência do Supremo Tribunal Federal, "a satisfação da exigência concernente à dupla punibilidade constitui requisito essencial ao deferimento do pedido extradicional" (Ext 683, Relator(a): Min. CELSO DE MELLO, Tribunal Pleno, Dje de 21.11.2008). Nessa linha, tanto o Estatuto do Estrangeiro (art. 77, VI), quanto o próprio tratado de extradição firmado entre o Brasil e o Estado requerente (art. III, c), vedam categoricamente a extradição quando extinta a punibilidade pela prescrição, à luz do ordenamento jurídico brasileiro ou do Estado requerente.

2. O Estado requerente imputa ao extraditando a prática de delito equivalente ao de associação criminosa (art. 288 do Código Penal), durante os anos de 1973 a 1975, e, no ano de 1974, de crimes equivalentes aos de sequestro qualificado (art. $148, \S 2^{\circ}$, do Código Penal) e de homicídio qualificado (art. 121, § $2^{\circ}$, do Código Penal). Evidentemente, todos esses delitos encontram-se prescritos, porquanto, desde sua consumação, transcorreu tempo muito superior ao prazo prescricional máximo previsto no Código Penal, equivalente a 20 (vinte) anos (art. 109, I). Não consta dos autos, ademais, que se tenha configurado qualquer das causas interruptivas da prescrição.

3. A circunstância de o Estado requerente ter qualificado os delitos imputados ao extraditando como de lesa-humanidade não afasta a sua prescrição, porquanto (a) o Brasil não subscreveu a Convenção sobre a Imprescritibilidade dos Crimes de Guerra e dos Crimes contra a Humanidade, nem aderiu a ela; e (b) apenas lei interna pode dispor sobre prescritibilidade ou imprescritibilidade da pretensão estatal de punir (cf. ADPF 153, Relator(a): Min. EROS GRAU, voto do Min. CELSO DE MELLO, Tribunal Pleno, Dje de 6.8.2010). 4. O indeferimento da extradição com base nesses fundamentos não ofende o art. 27 da Convenção de Viena sobre o Direito dos Tratados (Decreto 7.030/2009), uma vez que não se trata, no presente caso, de invocação de limitações de direito interno para justificar o inadimplemento do tratado de extradição firmado entre o Brasil e a Argentina, mas sim de simples incidência de limitação veiculada pelo próprio tratado, o qual veda a concessão da extradição "quando a ação ou a pena já estiver prescrita, segundo as leis do Estado requerente ou requerido" (art. III, c). 5. Pedido de extradição indeferido.

Por outro lado, tratando-se de matéria processual ou mesmo de matéria de direito material penal, porém, sem infringência aos princípios limitadores do poder punitivo estatal, é perfeitamente possível o controle de convencionalidade nos termos delineados pelo Supremo Tribunal Federal.

Em relação a direito processual penal, um bom exemplo é a audiência de custódia, expressão mencionada pela primeira vez em 1966 no Pacto Internacional sobre Direitos Civis e Políticos, que em seu artigo $9^{\circ}$, item 3 , assim estabelece:

"3. Qualquer pessoa presa ou encarcerada em virtude de infração penal deverá ser conduzida, sem demora, à presença do juiz ou de outra autoridade 
habilitada por lei a exercer funções judiciais e terá o direito de ser julgada em prazo razoável ou de ser posta em liberdade. A prisão preventiva de pessoas que aguardam julgamento não deverá constituir a regra geral, mas a soltura poderá estar condicionada a garantias que assegurem o comparecimento da pessoa em questão à audiência, a todos os atos do processo e, se necessário for, para a execução da sentença (grifo não original)”.

No mesmo sentido, dispôs a Convenção Americana sobre Direitos Humanos, (Pacto de São Jose da Costa Rica), em seu artigo $7^{\circ}$, item 5:

"5. Toda pessoa detida ou retida deve ser conduzida, sem demora, à presença de um juiz ou outra autoridade autorizada pela lei a exercer funções judiciais e tem direito a ser julgada dentro de um prazo razoável ou a ser posta em liberdade, sem prejuízo de que prossiga o processo. Sua liberdade pode ser condiciona a garantias que assegurem o seu comparecimento em juízo".

Ocorre que o Código de Processo Penal não dispõe sobre a apresentação do preso à autoridade judicial logo após a sua prisão, mas tão somente sobre a comunicação da referida prisão. Neste sentido, confira-se o teor do artigo 306 do referido código, cuja redação foi dada pela Lei $n^{\circ} 12.403 / 2011$ :

Art. 306. A prisão de qualquer pessoa e o local onde se encontre serão comunicados imediatamente ao juiz competente, ao Ministério Público e à família do preso ou à pessoa por ele indicada.

$\S 1$ o Em até 24 (vinte e quatro) horas após a realização da prisão, será encaminhado ao juiz competente o auto de prisão em flagrante e, caso o autuado não informe o nome de seu advogado, cópia integral para a Defensoria Pública. $\S 2^{\circ}$ No mesmo prazo, será entregue ao preso, mediante recibo, a nota de culpa, assinada pela autoridade, com o motivo da prisão, o nome do condutor e os das testemunhas.

Diante desta evidente antinomia entre a lei processual penal brasileira e as convenções internacionais sobre direitos humanos acima mencionadas, ratificadas e em vigor no país, porém, sem seguir o rito previsto no artigo $5^{\circ}, \S 3^{\circ}$ da Constituição Federal, alguns juízes e tribunais passaram a realizar o controle de convencionalidade e, em consequência, determinar a realização daaudiência de custódia. Neste sentido, decidiu a Egrégia Corte do Estado do Paraná, ao julgar, em 23 de abril de 2015, o Processo n 1358323-2, cujoacórdãofoi Relatado pelo Desembargador José Laurindo de Souza Netto:

EMENTA: HABEAS CORPUS - TRÁFICO DE DROGAS - DENÚNCIA PELO ARTIGO 33, CAPUT DA LEI N ${ }^{\circ} 11.343 / 06$ - PRISÃO EM FLAGRANTE CONVERTIDA EM PREVENTIVA - AUDIÊNCIA DE CUSTÓDIA PREVISÃO EM PACTOS E TRATADOS INTERNACIONAIS RATIFICADOS PELO BRASIL - CONTROLE DE CONVENCIONALIDADE - EFETIVAÇÃO DOS DIREITOS HUMANOS PREVISTOS NA ORDEM INTERNACIONAL - REQUISITOS DA PRISÃO - FUNDAMENTAÇÃO COM BASE NA QUANTIA CONSIDERÁVEL DE DROGAS - AUSÊNCIA DE MELHOR TÉCNICA - FALTA DE CONEXÃO LÓGICA - QUANTIDADE CONCRETAMENTE APREENDIDA QUE NÃO SE 
REVELA EXPRESSIVA - AUSÊNCIA DE PERIGO CONCRETO - MEDIDAS CAUTELARES ALTERNATIVAS - CIRCUNSTÂNCIAS DO CASO QUE INDICAM A NECESSIDADE E ADEQUAÇÃO DE SUA APLICAÇÃO ARTIGO 282 DO CÓDIGO DE PROCESSO PENAL - ORDEM CONHECIDA E CONCEDIDA POR UNANIMIDADE.

O primeiro Estado da federação que buscou implementar a diretriz internacional, em atenção às convenções ratificadas pelo Brasil e ao entendimento exarado pelo Supremo Tribunal Federal no julgamento conjunto efetuado pelo Plenário do Recurso Extraordinário ${ }^{\circ}$ 466.343/SP, do Recurso Extraordinário no 349.703/RS e dos Habeas Corpus n 87.585/TO e n ${ }^{\circ}$ 92.566/SP, relativo à norma supralegal, foi o Estado de São Paulo.

Com efeito, em 22 de janeiro de 2015, o Presidente do Tribunal de Justiça do Estado de São Paulo conjuntamente com o Corregedor Geral da Corregedoria Geral da Justiça assinou o Provimento Conjunto $n^{\circ}$ 03/2015 que previa e regulamentava os primeiros passos para a efetivação das audiências de custódia no Estado de São Paulo. Em 06 de fevereiro daquele mesmo ano, o Conselho Nacional de Justiça (CNJ) lançou oficialmente o Projeto Audiência de Custódia em parceria com o Tribunal de Justiça do Estado de São Paulo e iniciou, em nível experimental, as primeiras audiências de custódia no país. Na sequência, em 09 de abril do mesmo ano, o CNJ, o Ministério da Justiça e o Instituto de Defesa do Direito de Defesa (IDDD) assinaram 03 (três) acordos que têm por objetivo incentivar a difusão do projeto Audiências de Custódia no Brasil.

É bom ressaltar, entretanto, que o entendimento acerca da supralegalidade foi exarado pela Corte Suprema em recursos comuns, não dotados de efeito vinculante ${ }^{15}$, razão pela qual houve quem continuou a entender que os tratados e convenções de direitos humanos ratificados e em vigor no Brasil sem seguir o rito previsto no artigo $5^{\circ}, \S 3^{\circ}$ da Constituição Federal possuem status de norma ordinária e quem, sem adentrar em tal celeuma, simplesmente afastou a necessidade da audiência de custódia pela ausência de previsão legal no ordenamento jurídico interno, confira-se:

"Não obstante o Pacto de San José da Costa Rica assegure o direito à audiência
de custódia, nosso Código de Processo Penal não a prevê especificamente, não se
podendo falar em nulidade se não existe norma cogente nesse sentido.
(...) Considerando que referido Decreto não ingressou para a legislação brasileira
nos termos previstos pela Constituição Federal, em seu art. $5^{\circ}$, $\$ 3^{\circ}$, onde
ingressam como Emendas Constitucionais quando se tratar de matéria atinente a

${ }^{15}$ A supralegalidade dos tratados e convenções de direitos humanos ratificados pelo Brasil sem seguir o quórum qualificado previsto no artigo $5^{\circ}$, $\S 3^{\circ}$ da CF/88 foi assentada no julgamento conjunto do RE 466.343/SP, RE 349.703/RS, HC 87.585/TO e HC 92.566/SP, que tratava da questão da prisão do depositário infiel, realizado em 03.12.2008. O efeito de tais recursos estende-se somente às partes e, justamente por isso, em 23.12.2009 foi publicada a Súmula Vinculante 25 que assim dispõe: "é ilícita a prisão civil de depositário infiel, qualquer que seja a modalidade do depósito"(STF, 2009). 
direitos humanos, desde que em cada Casa do Congresso Nacional tenha ocorrido em dois turnos sua aprovação, por 3/5 dos votos dos respectivos membros, anotando-se que referida modificação foi acrescida pela EC n ${ }^{\circ} 45 / 2004$, não tem aplicação à hipótese referido parágrafo.

Dessa forma, tendo ingressado como Decreto, na Pirâmide de Kelsen da hierarquia das leis, decreto se encontra na mesma posição que as leis ordinárias.

Se o Código de Processo Penal não previu apresentação imediata do preso fisicamente ao juiz, referida apresentação não pode ser criada por ato do Conselho Nacional de Justiça ou do Tribunal de Justiça de São Paulo, já que se trata de matéria processual que só pode ser objeto de deliberação pelo Poder Legislativo Federal.

Sem qualquer razão, portanto, o argumento do impetrante de que estar-se-ia a frente a eventual nulidade pela não apresentação do preso ao juiz (TJSP $-5^{\mathrm{a}}$ Câmara de Direito Criminal - HC no 2090769-98.2015.8.26.0000 - Rel. Desembargador José Damião Pinheiro Machado Cogan, j. 06.08.2015).

Ocorre que, em 15 de dezembro de 2015, foi assinada pelo Conselho Nacional de Justiça a Resolução 213, que traz de maneira pormenorizada as diretrizes e previsões acerca da audiência de custódia para sua aplicação no território nacional. Desde então, ainda que sem legislação específica tratando do tema, vários outros Tribunais de Justiça lançaram diversos projetos objetivando o cumprimento das determinações impostas e, atualmente, as audiências de custódia se encontram em diferentes graus de aplicação em cada estado da federação.

Em relação à aplicabilidade do controle de convencionalidade ao direito material penal, o primeiro caso de grande expressão refere-se à sentença prolatada pelo MM Juiz de Direito Alexandre Moraes da Rosa, no julgamento dos autos n. 0067370-64.2012.8.26.0023, da Comarca de Florianópolis, Santa Catarina, na qual, utilizando o mecanismo referido, reconheceu a inexistência do crime de desacato em um ambiente democrático, nos seguintes termos:

“(...) No que concerne especificamente ao chamado controle de convencionalidade das leis, inarredável a menção ao julgamento do Recurso Extraordinário 466.343, da relatoria do Ministro Gilmar Mendes, no qual ficou estabelecido o atual entendimento do Supremo Tribunal Federal no que diz respeito à hierarquia das normas jurídicas no direito brasileiro. Assentou o STF que os tratados internacionais que versem sobre matéria relacionada a Direitos Humanos têm natureza infraconstitucional e supralegal - à exceção dos tratados aprovados em dois turnos de votação por três quintos dos membros de cada uma das casas do Congresso Nacional, os quais, a teor do art. $5^{\circ}, \S 3^{\circ}$, CR, os quais possuem natureza constitucional.

(...)Por conseguinte, cumpre ao julgador afastar a aplicação de normas jurídicas de caráter legal que contrariem tratados internacionais versando sobre Direitos Humanos, destacando-se, em especial, a Convenção Americana de Direitos Humanos de 1969 (Pacto de São José da Costa Rica), o Pacto Internacional sobre Direitos Civis e Políticos de 1966 e o Pacto Internacional dos Direitos Econômicos, Sociais e Culturais de 1966 (PIDESC), bem como as orientações expedidas pelos denominados "treatybodies" - Comissão Internamericana de 
Direitos Humanos e Conselho de Direitos Humanos das Nações Unidas, dentre outros - e a jurisprudência das instâncias judiciárias internacionais de âmbito americano e global - Corte Interamericana de Direitos Humanos e Tribunal Internacional de Justiça da Organização das Nações Unidas, respectivamente.

Nesse sentido, destaque-se que no âmbito da Comissão Interamericana de Direitos Humanos foi aprovada, no ano 2000, a Declaração de Princípios sobre a Liberdade de Expressão, tendo tal documento como uma de suas finalidades a de contribuir para a definição da abrangência do garantia da liberdade de expressão assegurada no art. 13 da Convenção Americana de Direitos Humanos. E, dentre os princípios consagrados na declaração, estabeleceu-se, em seu item "11", que "as leis que punem a expressão ofensiva contra funcionários públicos, geralmente conhecidas como 'leis de desacato', atentam contra a liberdade de expressão e o direito à informação."

Considerada, portanto, a prevalência do art. 13 da Convenção Americana de Direitos Humanos sobre os dispositivos do Código Penal, é inarredável a conclusão de Galvão de que "a condenação de alguém pelo Poder Judiciário brasileiro pelo crime de desacato viola o artigo 13 da Convenção Americana sobre os Direitos Humanos, consoante a interpretação que lhe deu a Comissão Interamericana de Direitos Humanos".

Em que pese reconhecer-se a inexistência, a priori, de caráter vinculante na interpretação do tratado operada pela referida instituição internacional, filio-me ao entendimento apresentado, considerando, antes de tudo, os princípios da fragmentariedade e da interferência mínima, os quais impõem que as condutas de que deve dar conta o Direito Penal são essencialmente aquelas que violam bens jurídicos fundamentais, que não possam ser adequadamente protegidos por outro ramo do Direito. Nesse prisma, tenho que a manifestação pública de desapreço proferida por particular, perante agente no exercício da atividade Administrativa, por mais infundada ou indecorosa que seja, certamente não se consubstancia em ato cuja lesividade seja da alçada da tutela penal. Trata-se de previsão jurídica nitidamente autoritária - principalmente em se considerando que, em um primeiro momento, caberá à própria autoridade ofendida (ou pretensamente ofendida) definir o limiar entre a crítica responsável e respeitosa ao exercício atividade administrativa e a crítica que ofende à dignidade da função pública, a qual deve ser criminalizada. A experiência bem demonstra que, na dúvida quanto ao teor da manifestação (ou mesmo na certeza quanto à sua lidimidade), a tendência é de que se conclua que o particular esteja desrespeitando o agente público - e ninguém olvida que esta situação, reiterada no cotidiano social, representa infração à garantia constitucional da liberdade de expressão" (EMPORIO DO DIREITO, 2015).

Após isto, vieram outras decisões no mesmo sentido e até o Colendo Superior Tribunal de Justiça, aos 15 de dezembro de 2016, manifestou-se sobre o tema. Na ocasião, a $5^{\text {a }}$ Turma do Tribunal da Cidadania, ao julgar Recurso Especial1640084/SP, apresentado pela Defensoria Pública do Estado de São Paulo, realizou controle de convencionalidade e concluiu que o tipo penal descrito no artigo 331 do Código Penal, que trata do desacato, é incompatível com a Convenção Americana de Direitos Humanos.

Não obstante, depois da decisão acima descrita, proferida pela $5^{\text {a }}$ Turma, o colegiado afetou oHabeas Corpus 379269/MS para que a Terceira Seção, que reúne as 02 (duas) Turmas que julgam Direito Penal no Superior Tribunal de Justiça ( $5^{\mathrm{a}}$ e $6^{\mathrm{a}}$ Turmas), pacificasse a questão. 
No julgamento ocorrido em 24 de maio de 2017, prevaleceu o entendimento do Ministro Antônio Saldanha Palheiro, designado para lavratura do Acórdão, no sentido de que o crime de desacato previsto no artigo 331 do Código Penal é compatível com o Pacto de São José da Costa Rica. O Ministro, após consignar que a Comissão Interamericana de Direitos Humanos não possui função jurisdicional e que suas recomendações não possuem força vinculante, ressaltou que não existe direito absoluto e que a própria Convenção Americana de Direitos Humanos apresenta as condições indispensáveis para que se admita eventual restrição à liberdade de expressão, as quais foram preenchidas pelo dispositivo que trata do desacato no Brasil.

No mesmo sentido, aliás, decidiu o Colendo Supremo Tribunal Federal. Em julgamento proferido em 13 de março de 2018, nos autos do Habeas Corpus 141949/DF, de relatoria do Ministro Gilmar Mendes, ficou consignado que a criminalização do desacato se mostra compatível com o Estado Democrático de Direito. O Relator afirmou que, em controle de convencionalidade, não se verifica qualquer afronta ao Pacto de São José da Costa Rica, vez que o referido Pacto dispõe claramente que o exercício do direito à liberdade de pensamento e de expressão, embora não sujeito à censura prévia, deve assumir responsabilidades ulteriores, expressamente fixadas em lei, para assegurar o respeito aos direitos ou à reputação das demais pessoas. Para ele, o direito à liberdade de expressão deve harmonizar-se com os demais direitos envolvidos (honra, intimidade e dignidade), não eliminá-los. O desacato, portanto, constitui importante instrumento de preservação da lisura da função pública e, indiretamente, da própria dignidade de quem a exerce.

Como se pode observar, é plenamente possível a realização de controle de convencionalidade no âmbito penal. Tendo sido o Código Penal e o Código de Processo Penal recepcionados pela Constituição Federal como leis ordinárias, é perfeitamente possível a aferição da compatibilidade de tais códigos e das demais leis que tratam de matéria penal com a norma supralegal, no caso tratados e convenções internacionais sobre direitos humanos internalizados conforme artigo $5^{\circ}, \S 2^{\circ}$ da Constituição Federal, ou seja, sem seguir o procedimento previsto no $\S 3^{\circ}$ do referido dispositivo constitucional.

Requer-se, entretanto, a observação dos princípios fundamentais em matéria penal, sob pena de desvirtuamento dos próprios ideais do Estado Democrático de Direito. O controle de convencionalidade, portanto, não pode resultar em violação ao princípio da legalidade, da intervenção mínima, da ofensividade, do non bis in idem e da culpabilidade. 
Outra questão bastante relevante refere-se à segurança jurídica ${ }^{16}$. Conforme delineado pelo Excelso Pretório, o controle de convencionalidade deve ocorrer pela via difusa que, tradicionalmente, surte efeitos não vinculantes e apenas entre as $\operatorname{partes}^{17}$. O problema é que o Direito Penal lida com um dos bens mais caros do ser humano, qual seja a liberdade e, permitir a realizaçãodo controle de convencionalidade por qualquer juiz, acaba por trazer decisões conflitantes, como demonstrado acima, em que alguns foram absolvidos da acusação de terem praticado o delito de desacato e outros, condenados. Prejudica-se a segurança jurídica e, simultaneamente, fere-se o princípio da isonomia.

Portanto, ainda que possível o controle de convencionalidade em âmbito penal, é necessário que a legislação discipline tal instituto ou mesmo que os Tribunais Superiores assentem critérios mais rígidos para sua utilização, preservando-se os princípios que fundamentam o sistema penal e garantindo a segurança jurídica e a isonomia.

\section{CONCLUSÃO}

Conforme demonstrado ao longo deste ensaio, a partir de uma decisão proferida pelo Colendo Supremo Tribunal Federal no fim do ano de 2008, passou-se a entender que os tratados e convenções de direitos humanos ratificados pelo Brasil sem seguir o rito de aprovação referente ao quórum qualificado de emenda seriam considerados normas supralegais, estando abaixo da Constituição Federal e acima das leis infraconstitucionais, numa posição intermediária.

\footnotetext{
16 Sobre o tema: "O princípio da segurança jurídica determina a busca dos ideais de cognoscibilidade, confiabilidade e calculabilidade no direito. (...) Como o princípio da segurança jurídica delimita os contornos daquilo que é indispensável para que o cidadão possa, de acordo com o direito, plasmar o seu presente e planejar, livre e autonomamente, sem engano ou injustificada surpresa, o seu futuro, inquiri-lo é, a um só tempo, investigar, de um lado, os direitos de liberdade, de igualdade e de dignidade, e de outro, os princípios relativos à atuação estatal. Mais do que isso: os ideais que o integram revelam, indiretamente, o tipo de sociedade que se visa a constituir, pelos tipos de Estado e de cidadão que resultam da sua configuração. A exigência de cognoscibilidade permite que o cidadão possa 'saber' aquilo que 'pode ou não fazer' de acordo com o direito. Essa exigência, dentro de um estado de confiabilidade e de calculabilidade, capacita-o a, com autonomia e com liberdade, 'fazer ou não fazer', de modo que possa 'ser ou não ser' aquilo que deseja e que tem condições de ser. A segurança jurídica, em outras palavras, é um instrumento para que o cidadão possa saber, antes, e com seriedade, o que pode fazer, de modo que possa melhor ser o que pode e quer ser" (ÁVILA,2012, p. 95).

${ }^{17}$ Diz-se tradicionalmente porque o Supremo Tribunal Federal, em julgamento ocorrido aos 29 de novembro de 2017, passou a adotar a teoria da abstrativização do controle difuso de constitucionalidade. Assim, se o Plenário do STF decidir a constitucionalidade ou inconstitucionalidade de uma lei ou ato normativo, ainda que em controle difuso, essa decisão terá os mesmos efeitos do controle concentrado, ou seja, eficácia erga omnes e vinculante (STF. Plenário. ADI 3406/RJ e ADI 3470/RJ, Rel. Min. Rosa Weber, julgados em 29/11/2017). Não obstante, ainda não houve nenhuma manifestação no sentido de que o controle de convencionalidade, realizado de maneira difusa, tenha passado a surtir efeitos erga omnes, de modo que, em relação a este tipo de controle, permanece os efeitos tradicionais, quais sejam inter partes e não vinculante.
} 
Diante disto, criou-se o chamado controle de convencionalidade, ou seja, um mecanismo de aferição da compatibilidade material das leis infraconstitucionais com os diplomas internacionais daquela natureza que lhe são superiores.

Assim, no ordenamento jurídico brasileiro, passou a ser possível o controle de constitucionalidade, cujo parâmetro são as normas integrantes do bloco de constitucionalidade (ADCT, normas constitucionais e tratados e convenções internacionais sobre direitos humanos internalizados nos termos do art. $5^{\circ}, \S 3^{\circ}$ da $\mathrm{CF}$ ); o controle de convencionalidade, cujo parâmetro são os tratados e convenções internacionais sobre direitos humanos internalizados sem observância ao rito estabelecido no artigo $5^{\circ}, \S 3^{\circ}$ da Constituição Federal (ex. Pacto de São José da Costa Rica) e o controle de legalidade, cujo parâmetro são as leis infraconstitucionais (aqui, analisa-se, por exemplo, a compatibilidade entre o decreto regulamentador e lei a ser regulamentada).

Quanto ao controle de convencionalidade, após uma análise minuciosa do Direito Penal, no que tange a sua conceituação e princípios fundamentais, foi possível concluir que, observados alguns limites (no caso, a prevalência dos princípios fundamentais) é possível sim o controle de convencionalidade no âmbito penal, mormente porque as normas penais são veiculadas por meio de leis ordinárias e, portanto, devem ser compatíveis com os tratados e convenções internacionais sobre direitos humanos internalizados sem seguir o quórum qualificado de aprovação previsto no artigo $5^{\circ}, \S^{\circ}$ da Carta Magna.

E tanto é possível o controle de convencionalidade na seara penal que, conforme demonstrado neste trabalho, já vem sendo feito pelos juízes e tribunais brasileiros.

Ocorre que, da maneira como pensado pelo Excelso Pretório, o controle de convencionalidade apenas pode ser realizado de maneira difusa, o que tem gerado bastante insegurança jurídica, dada o surgimentos de decisões absolutamente distintas para casos idênticos (exemplo claro é a situação do desacato, ora considerado fato atípico, ora considerado crime).

Urge, portanto, estabelecer critérios mais rigorosos para a realização do controle de convencionalidade na seara penal, seja através de lei regulamentadora, seja através de mecanismos vinculantes a disposição dos Tribunais Superior, de modo a se preservar não só a segurança jurídica, mas principalmente o princípio da isonomia. 


\section{REFERÊECIAS.}

ALVES, J. A. Lindgren. A arquitetura internacional dos Direitos humanos. São Paulo: FTD, 1997.

AVILA, Humberto. Segurança jurídica: entre permanência, mudança e realização no direito tributário. 2. ed. São Paulo: Malheiros, 2012.

BECCARIA, Cesare. Dos delitos e das penas. Tradução de Guiodicini e Alessandro Berti Contessa. Martins Fontes: São Paulo, 2005.

BERNARDES, Juliano Taveira. FERREIRA, Olavo Augusto Vianna Alves. Direito Constitucional. Teoria da Constituição. Tomo I. 5 ed. rev, ampl e atual. Bahia, JusPODIVM, 2015.

Teoria da Constituição. Tomo II. 5 ed. rev, ampl e atual. Bahia, JusPODIVM, 2015.

\section{BIBLIOTECA VIRTUAL DE DIREITOS HUMANOS DA UNIVERSIDADE DE SÃO}

PAULO - USP: banco de dados. Disponível em

$<$ http://www.direitoshumanos.usp.br/index.php/Documentos-anteriores-\%C3\%A0-

cria\%C3\%A7\%C3\%A3o-da-Sociedade-das-Na\%C3\%A7\%C3\%B5es-at\%C3\%A9-

1919/declaracao-de-direitos-do-homem-e-do-cidadao-1789.html>.

BITENCOURT, Cezar Roberto. Tratado de Direito Penal. Parte geral. 1 vol. 21 ed. rev. e atual. São Paulo: Saraiva, 2015.

BRASIL. Constituição da República Federativa do Brasil de 1988. Disponível em <http://www.planalto.gov.br/ccivil_03/Constituicao/Constituicao.htm>.

BRASIL. Decreto ${ }^{\circ}$ 592, de 06 de julho de 1992. Promulga o Pacto internacional sobre Direitos Civis e Políticos, de 16 de setembro de 1966. Disponível em <http://www.planalto.gov.br/ ccivil_03/decreto/1990-1994/d0592.htm>.

BRASIL. Decreto $n^{\circ}$ 678, de 06 de novembro de 1992. Promulga a Convenção Americana sobre Direitos Humanos (Pacto de São José da Costa Rica), de 22 de novembro de 1969. Disponível em <http://www.planalto.gov.br/ccivil_03/decreto/d0678.htm>.

BRASIL. Decreto $n^{\circ} 4388$, de 25 de setembro de 2002. Promulga o Estatuto de Roma do Tribunal Penal Internacional, de 17 de julho de 1998. Disponível em <http://www.planalto.gov.br/ccivil_03/decreto/2002/D4388.htm>.

BRASIL. Decreto $n^{\circ}$ 6.949, de 25 de agosto de 2009. Promulga a Convenção Internacional sobre os Direitos das Pessoas com Deficiência e seu Protocolo Facultativo, de 30 de março de 2007. Disponível em <http://www.planalto.gov.br/ccivil_03/_ato2007-

2010/2009/decreto/d6949.htm>.

CAVALCANTE, Márcio André Lopes. Informativo comentado: Informativo 888 do STF. Dizer o Direito. Disponível em <https://dizerodireitodotnet.files.wordpress.com/2018/01/info888-stf.pdf>. 
COMISSÃO INTERAMERICANA DE DIREITOS HUMANOS. Convenção Americana Sobre Direitos Humanos. Disponível em:<https://www.cidh.oas.org/ basicos/portugues/c.convencao_americana.htm>.

CONDE, Francisco Muñoz. ARÁN, Mercedes García. Derecho Penal. Parte General. $8^{\text {a }}$ ed. revisada y puesta al día. Valencia, Espana: TirantloBlanch, 2010.

CORTE INTERAMERICANA DE DIREITOS HUMANOS. Caso AlmonacidArellano e outros Vs. Chile. Sentença de 26 de setembro de 2006. Disponível em <www.corteidh.or.cr/docs/ casos/articulos/seriec_154_por.doc $>$.

Desacato não é crime, diz juiz em controle de convencionalidade. Empório do Direito, São Paulo, 21 março 2015. Disponível em <https://emporiododireito.com.br/leitura/desacato-naoe-crime-diz-juiz-em-controle-de-convencionalidade>

GOMES, Luís Flávio. Prefácio. In. MAZZUOLI, Valério de Oliveira. O controle jurisdicional da convencionalidade das leis. 4 ed. São Paulo: Revista dos Tribunais, 2016.

GOVERNO DO BRASIL. Atos Internacionais. Disponível em <http://www.brasil.gov.br/governo/ 2012/05/atos-internacionais>.

GRECO, Rogério. Curso de Direito Penal. 17 ed. Rio de Janeiro: Impetus, 2015.

JUNQUEIRA, Gustavo. VANZOLINI. Patrícia. Manual de Direito Penal. São Paulo: Saraiva, 2013.

MAZZUOLI, Valério de Oliveira. O controle jurisdicional da convencionalidade das leis. 4 ed. São Paulo: Revista dos Tribunais, 2016.

MENDES, Gilmar Ferreira; BRANCO, Paulo Gustavo Gonet. Curso de Direito Constitucional. 9 ed. São Paulo: Saraiva, 2014.

NAÇÕES UNIDAS. Brasil. Declaração Universal dos Direitos Humanos das Nações Unidas. Disponível em <https://nacoesunidas.org/wp-content/uploads/2018/10/DUDH.pdf>.

NUCCI, Guilherme de Souza. Manual de direito penal: parte geral. 7 ed. atual. ampl. São Paulo: Revista dos Tribunais, 2011.

OLIVÉ, Juan Carlos Ferré. PAZ, Miguel ÁngelNúñez. OLIVEIRA, William Terra de. BRITO, Alexis Couto de. Direito Penal brasileiro: parte geral: princípios fundamentais e sistema. 2 ed. São Paulo: Saraiva, 2017.

PIOVESAN, Flávia. Direitos humanos e o direito constitucional internacional. 2 ed. São Paulo: Max Limonad, 1997.

ROXIN, Claus. Derecho Penal. Parte General. Fundamentos. La Estructura de la Teoría del Delito. Tomo I. Madrid: Thomson Civitas, 2008. 
Prólogo. In.OLIVÉ, Juan Carlos Ferré. PAZ, Miguel ÁngelNúñez. OLIVEIRA, William Terra de. BRITO, Alexis Couto de. Direito Penal brasileiro: parte geral: princípios fundamentais e sistema. 2 ed. São Paulo: Saraiva, 2017.

SARLET, Ingo Wolfgang.Integração dos tratados de Direitos Humanos no ordenamento jurídico. Direitos Fundamentais. Revista Consultor Jurídico, março.2015a. Disponível em $<$ https://www.conjur.com.br/2015-mar-27/direitos-fundamentais-integracao-tratados-direitoshumanos-ordenamento-juridico>.

Controle de Convencionalidade dos Tratados Internacionais. Direitos Fundamentais. Revista Consultor Jurídico, abril.2015b. Disponível em <https://www.conjur.com.br/2015abr-10/direitos-fundamentais-controle-convencionalidade-tratados-internacionais $>$.

SUPERIOR TRIBUNAL DE JUSTIÇA: banco de jurisprudência. Disponível em <www.stj.jus.br>.

SUPREMO TRIBUNAL FEDERAL: banco de jurisprudência. Disponível em <www.stf.jus.br>.

TRIBUNAL DE JUSTIÇA DE PARANÁ: banco de jurisprudência. Disponível em <www.tjpr.jus.br>.

TRIBUNAL DE JUSTIÇA DE SÃO PAULO: banco de jurisprudência. Disponível em <www.tjsp.jus.br>.

ZAFFARONI, Eugênio Raúl, PIERANGELI, José Henrique. Manual de Direito Penal Brasileiro. 1vol. 9 ed. rev. e atual. São Paulo: Revista dos Tribunais, 2011.

Trabalho recebido em 27 de junho de 2019

Aceito em 31 de maio de 2020 